Key Words:

Portsmouth

Radioactive Decay

Retention:

Permanent

\title{
RECOMMENDED METHOD TO ACCOUNT FOR DAUGHTER INGROWTH FOR THE PORTSMOUTH ON-SITE WASTE DISPOSAL FACILITY (OSWDF) PERFORMANCE ASSESSMENT (PA) MODELING
}

Mark A. Phifer

Frank G. Smith, III

JUNE 21, 2013

Savannah River National Laboratory

Savannah River Nuclear Solutions

Aiken, SC 29808

Prepared for the U.S. Department of Energy Under

Contract Number DE-AC09-08SR22470

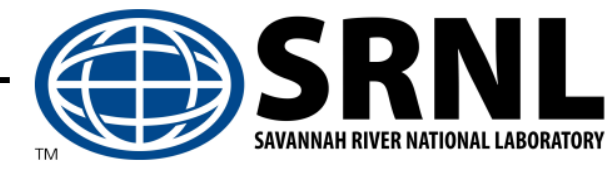


SRNL-STI-2013-00394

\section{DISCLAIMER}

This work was prepared under an agreement with and funded by the U.S. Government. Neither the U. S. Government or its employees, nor any of its contractors, subcontractors or their employees, makes any express or implied:

1. warranty or assumes any legal liability for the accuracy, completeness, or for the use or results of such use of any information, product, or process disclosed; or

2. representation that such use or results of such use would not infringe privately owned rights; or

3. endorsement or recommendation of any specifically identified commercial product, process, or service.

Any views and opinions of authors expressed in this work do not necessarily state or reflect those of the United States Government, or its contractors, or subcontractors.

Printed in the United States of America

Prepared for

U.S. Department of Energy 
Key Words:

Portsmouth

Radioactive Decay

Retention:

Permanent

\title{
RECOMMENDED METHOD TO ACCOUNT FOR DAUGHTER INGROWTH FOR THE PORTSMOUTH ON-SITE WASTE DISPOSAL FACILITY (OSWDF) PERFORMANCE ASSESSMENT (PA) MODELING
}

\author{
Mark A. Phifer
}

Frank G. Smith, III

June 21, 2013

Savannah River National Laboratory

Savannah River Nuclear Solutions

Savannah River Site

Aiken, SC 29808 


\section{REVIEWS AND APPROVALS}

M. A. Phifer, Author, Radiological Performance Assessment

Date

F. G. Smith, III, Author, Computational Sciences

Date

R. A. Hiergesell, Technical Reviewer, Radiological Performance Assessment

Date

D. A. Crowley, Manager, Radiological Performance Assessment

Date

R. S. Aylward, Manager, Environmental Restoration Technology

Date

- ii - 


\section{TABLE OF CONTENTS}

LIST OF FIGURES ...................................................................................................ii

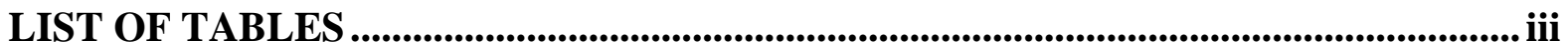

LIST OF ACRONYMS .................................................................................................... iv

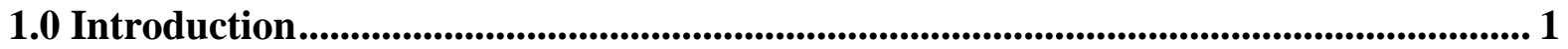

2.0 Method and Approach.............................................................................................................. 1

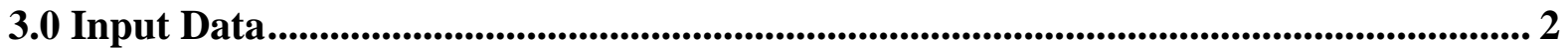

4.0 Model Results ........................................................................................................................ 8

5.0 Model Results Summary and Conclusions ........................................................................ 16

6.0 Recommendation................................................................................................................. 16

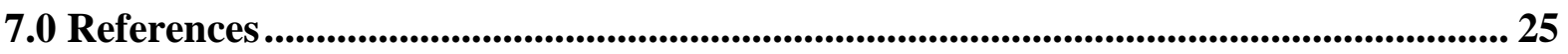

8.0 Attachment - Model Outputs ……..................................................................................... 25

\section{LIST OF FIGURES}

Figure 1. GoldSim Radioactive Decay and Daughter Ingrowth Model ....................2

Figure 2. Technetium-99 Decay to Stable Progeny .........................................5

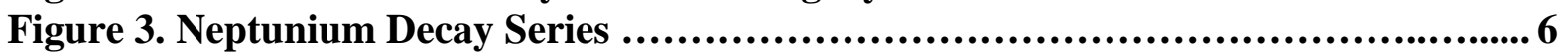

Figure 4. Uranium Decay Series .......................................................6 6

Figure 5. Actinium Decay Series ............................................................. 7

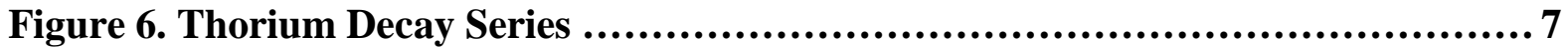

Figure 7. Portsmouth OSWDF Scenario 4 Inventory - Technetium-99 Decay ........... 10

Figure 8. Portsmouth OSWDF Scenario 4 Inventory - Neptunium Decay Series

Daughter Ingrowth ..................................................................... 11

Figure 9. Portsmouth OSWDF Scenario 4 Inventory - Uranium Decay Series

Daughter Ingrowth ................................................................... 12

Figure 10. Portsmouth OSWDF Scenario 4 Inventory - Actinium Decay Series

Daughter Ingrowth ................................................................... 13

Figure 11. Portsmouth OSWDF Scenario 4 Inventory - Thorium Decay Series

Daughter Ingrowth ................................................................. 14

\section{LIST OF TABLES}

Table 1. Portsmouth OSWDF Inventory Scenarios ......................................... 3

Table 2. Portsmouth OSWDF Decay Chains - Half-lives and Branching Fractions ..... 3

Table 3. Portsmouth OSWDF Scenario 4 Inventory - Decay Comparison ................. 15

Table 4. Neptunium Decay Series Daughter to Parent Ratios ............................19

Table 5. Uranium Decay Series Daughter to Parent Ratios ................................20

Table 6. Actinium Decay Series Daughter to Parent Ratios .............................. 22

Table 7. Thorium Decay Series Daughter to Parent Ratios .................................23

Table 8. Radionuclides with Little Activity Importance over the 100,000 Year

Period Modeled ............................................................................. 24 


\title{
LIST OF ACRONYMS
}

\author{
FBP Fluor-B\&W Portsmouth \\ GTC GoldSim Technology Group LLC \\ ICRP \\ International Commission on Radiological Protection \\ $\mathrm{K}_{\mathrm{d}} \mathrm{S}$ \\ Distribution coefficients \\ OSWDF \\ PA \\ On-Site Waste Disposal Facility \\ SRNL \\ Performance Assessment \\ STOMP \\ Savannah River National Laboratory \\ Subsurface Transport Over Multiple Phases
}




\subsection{INTRODUCTION}

A 3-D STOMP model has been developed for the Portsmouth On-Site Waste Disposal Facility (OSWDF) at Site D as outlined in Appendix K of FBP 2013. This model projects the flow and transport of the following radionuclides to various points of assessments: Tc-99, U-234, U-235, U-236, U-238, Am-241, Np-237, Pu-238, Pu-239, Pu-240, Th-228, and Th230. The model includes the radioactive decay of these parents, but does not include the associated daughter ingrowth because the STOMP model does not have the capability to model daughter ingrowth. The Savannah River National Laboratory (SRNL) provides herein a recommended method to account for daughter ingrowth in association with the Portsmouth OSWDF Performance Assessment (PA) modeling.

\subsection{METHOD AND APPROACH}

The recommendation has been developed using GoldSim Version 10.5 (GTC 2010), which does have the capability to model both radioactive decay and daughter ingrowth. In general, the approach taken was to start with the 19 radionuclides considered in the OSWDF PA analysis and develop full decay chains that include these species. This produced a total of 61 radionuclides that would occur in the OSWDF waste material over time from decay of the starting radionuclides and ingrowth of daughter products. The half-lives and decay chains for these 61 radionuclides were obtained from standard references (ICRP 2008) and entered as a list of species in the GoldSim model. A starting inventory of the 19 initial radionuclides was provided by Portsmouth (Abitz 2013). Starting with the provided inventory, the GoldSim model was then able to calculate the radionuclide composition of the waste over time for all 61 species in the decay chains assuming no transport out of the system (i.e. closed waste system). Figure 1 provides a pictorial representation of the radioactive decay and daughter ingrowth model developed by SRNL using GoldSim. Because this model does not consider transport, it effectively performs a Bateman 1910 calculation.

Results from the GoldSim analysis were used to develop daughter-to-parent ratios for the waste over time. It is recommended that these daughter-to-parent ratios be applied to the STOMP modeled parent concentrations at the points of assessment to produce an estimate of the daughter concentrations at the points of assessment. The resultant combined parent and daughter concentration can then be utilized within subsequent dose calculations.

As outlined this evaluation did not take into consideration transport but took the results from a closed waste system and applied them at the STOMP points of assessment. This means that distribution coefficients $\left(\mathrm{K}_{\mathrm{d}} \mathrm{s}\right)$, which impact transport to the point of assessment and the resulting concentration with time profile, were not evaluated herein. However the lack of transport and $\mathrm{K}_{\mathrm{d}}$ consideration in the evaluation is considered conservative. This evaluation assumes that all daughters arrive at the point of assessment with the parent (8 radionuclides considered parents) based upon ingrowth alone. This is considered a realistic assumption for all daughters with half-lives less than one year (i.e. 41 of the 61 radionuclides), because within the slow flow transport, geologic environment of the OSWDF such short-lived daughters could not migrate very far from the parent. Daughters with half-lives greater than 
one year (i.e. only 12 of the 61 radionuclides) could potentially migrate either faster or slower than the parent depending upon the differences in $\mathrm{K}_{d} \mathrm{~S}$, resulting in a different daughter concentration at the point of assessment for any point in time than based upon ingrowth alone. Such a consideration of $K_{d} S$ would most likely result in the peaks of the parents and daughters being separated in time resulting in a lower overall peak than would be calculated based upon ingrowth alone.

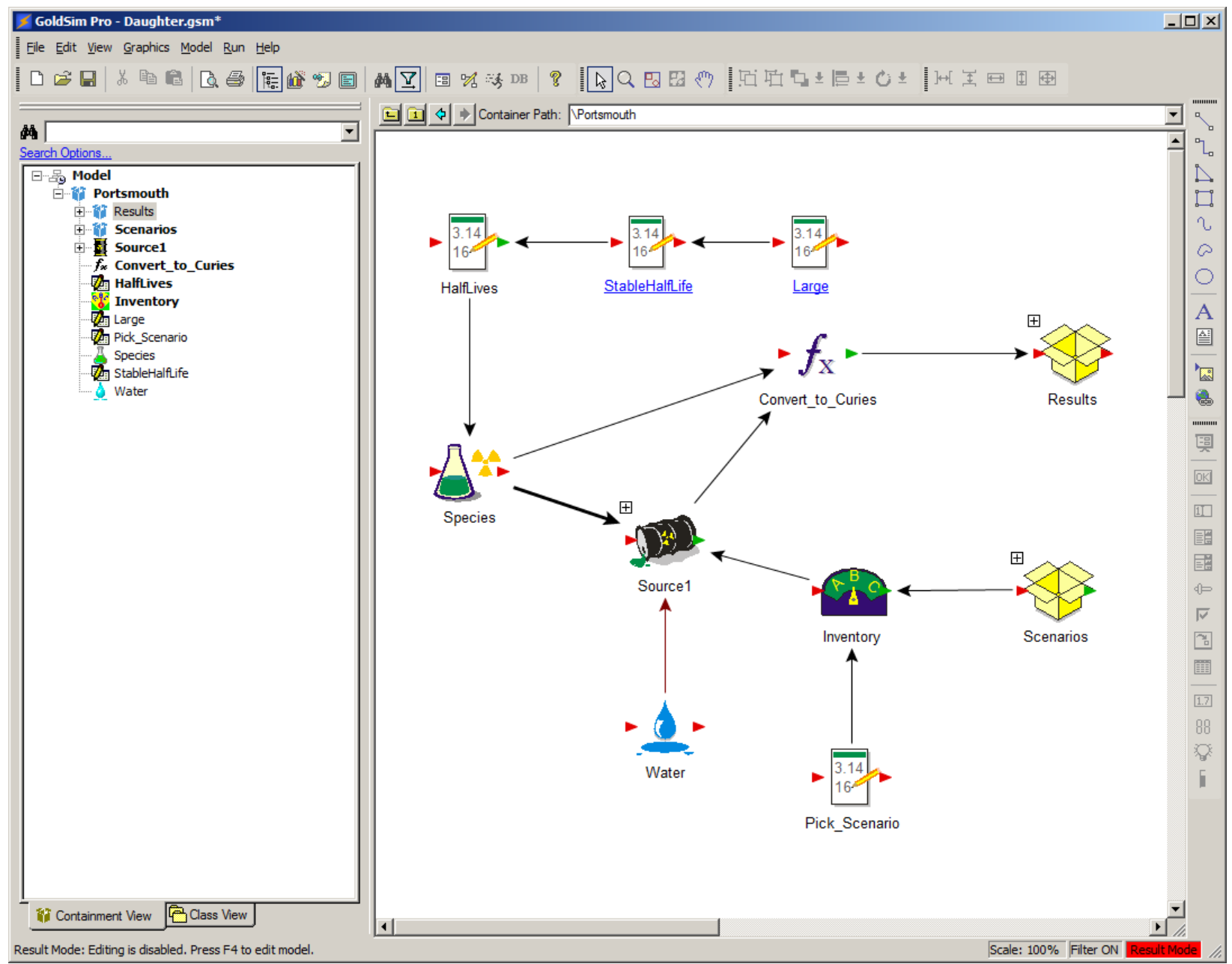

Figure 1. GoldSim Radioactive Decay and Daughter Ingrowth Model

\subsection{INPUT DATA}

Table 1 provides the estimated radionuclide inventory for four different OSWDF inventory scenarios as provided by Abitz 2013. The Scenario 4 inventory has been utilized to develop this recommendation because it has the greatest inventory. Table 2 provides the half-lives and branching fractions (ICRP 2008) associated with the decay chains of the radionuclides listed in Table 1. Figures 2 through 6 provide a pictorial representation of the five associated decay chains (Technetium-99, Neptunium, Uranium, Actinium, and Thorium). 
Table 1. Portsmouth OSWDF Inventory Scenarios

\begin{tabular}{|l|c|r|r|r|}
\hline \multicolumn{1}{|c|}{ Radionuclide } & $\begin{array}{c}\text { Scenario 1 } \\
\text { (Curies) }\end{array}$ & $\begin{array}{c}\text { Scenario 2 } \\
\text { (Curies) }\end{array}$ & $\begin{array}{c}\text { Scenario 3 } \\
\text { (Curies) }\end{array}$ & $\begin{array}{c}\text { Scenario 4 } \\
\text { (Curies) }\end{array}$ \\
\hline Tc99 & $1.53 \mathrm{E}+02$ & $2.45 \mathrm{E}+02$ & $2.31 \mathrm{E}+02$ & $3.79 \mathrm{E}+02$ \\
\hline Am241 & $8.43 \mathrm{E}-03$ & $1.53 \mathrm{E}-02$ & $9.99 \mathrm{E}-03$ & $1.71 \mathrm{E}-02$ \\
\hline Np237 & $7.03 \mathrm{E}-02$ & $1.17 \mathrm{E}-01$ & $9.22 \mathrm{E}-02$ & $1.41 \mathrm{E}-01$ \\
\hline Pa233 & $7.03 \mathrm{E}-02$ & $1.17 \mathrm{E}-01$ & $9.22 \mathrm{E}-02$ & $1.41 \mathrm{E}-01$ \\
\hline $\mathrm{U} 238$ & $5.81 \mathrm{E}+01$ & $7.90 \mathrm{E}+01$ & $6.51 \mathrm{E}+01$ & $8.76 \mathrm{E}+01$ \\
\hline Th234 & $5.81 \mathrm{E}+01$ & $7.90 \mathrm{E}+01$ & $6.51 \mathrm{E}+01$ & $8.76 \mathrm{E}+01$ \\
\hline Pa234m & $5.81 \mathrm{E}+01$ & $7.90 \mathrm{E}+01$ & $6.51 \mathrm{E}+01$ & $8.76 \mathrm{E}+01$ \\
\hline Pu238 & $6.13 \mathrm{E}-03$ & $1.00 \mathrm{E}-02$ & $7.21 \mathrm{E}-03$ & $1.12 \mathrm{E}-02$ \\
\hline U234 & $1.07 \mathrm{E}+02$ & $1.54 \mathrm{E}+02$ & $1.36 \mathrm{E}+02$ & $1.88 \mathrm{E}+02$ \\
\hline Th230 & $3.41 \mathrm{E}-01$ & $4.98 \mathrm{E}-01$ & $4.41 \mathrm{E}-01$ & $6.03 \mathrm{E}-01$ \\
\hline Pu239 & $7.63 \mathrm{E}-03$ & $2.00 \mathrm{E}-02$ & $8.84 \mathrm{E}-03$ & $2.17 \mathrm{E}-02$ \\
\hline $\mathrm{U} 235$ & $7.14 \mathrm{E}+00$ & $1.11 \mathrm{E}+01$ & $8.54 \mathrm{E}+00$ & $1.27 \mathrm{E}+01$ \\
\hline Th231 & $7.14 \mathrm{E}+00$ & $1.11 \mathrm{E}+01$ & $8.54 \mathrm{E}+00$ & $1.27 \mathrm{E}+01$ \\
\hline U236 & $1.23 \mathrm{E}+00$ & $1.54 \mathrm{E}+00$ & $1.43 \mathrm{E}+00$ & $1.78 \mathrm{E}+00$ \\
\hline Th232 & $8.33 \mathrm{E}-03$ & $1.21 \mathrm{E}-02$ & $1.01 \mathrm{E}-02$ & $1.41 \mathrm{E}-02$ \\
\hline Ra228 & $8.33 \mathrm{E}-03$ & $1.21 \mathrm{E}-02$ & $1.01 \mathrm{E}-02$ & $1.41 \mathrm{E}-02$ \\
\hline Ac228 & $8.33 \mathrm{E}-03$ & $1.21 \mathrm{E}-02$ & $1.01 \mathrm{E}-02$ & $1.41 \mathrm{E}-02$ \\
\hline Th228 & $8.33 \mathrm{E}-03$ & $1.21 \mathrm{E}-02$ & $1.01 \mathrm{E}-02$ & $1.41 \mathrm{E}-02$ \\
\hline Ra224 & $8.33 \mathrm{E}-03$ & $1.21 \mathrm{E}-02$ & $1.01 \mathrm{E}-02$ & $1.41 \mathrm{E}-02$ \\
\hline
\end{tabular}

Note to Table 1:

- All data obtained from Abitz 2013

Table 2. Portsmouth OSWDF Decay Chains - Half-lives and Branching Fractions

\begin{tabular}{|c|c|c|c|c|c|}
\hline Radionuclide & $\begin{array}{c}\text { Half-life } \\
\text { (years) }\end{array}$ & $\begin{array}{c}\text { Daughter } 1 \\
\text { Branching } \\
\text { Fraction }\end{array}$ & Daughter 1 & $\begin{array}{c}\text { Daughter } 2 \\
\text { Branching } \\
\text { Fraction }\end{array}$ & Daughter 2 \\
\hline Ac225 & 2.74E-02 & 1 & Fr221 & & \\
\hline Ac227 & $2.18 \mathrm{E}+01$ & 0.9862 & Th227 & 0.0138 & Fr223 \\
\hline Ac228 & 7.02E-04 & 1 & Th228 & & \\
\hline Am241 & $4.32 \mathrm{E}+02$ & 1 & Np237 & & \\
\hline At217 & $1.02 \mathrm{E}-09$ & 0.99988 & Bi213 & & \\
\hline At218 & 4.75E-08 & 0.999 & $\mathrm{Bi} 214$ & 0.001 & Rn218 \\
\hline Bi210 & $1.37 \mathrm{E}-02$ & 1 & Po210 & 1 & \\
\hline Bi211 & 4.07E-06 & 0.99724 & Tl207 & 0.00276 & Po211 \\
\hline $\mathrm{Bi} 212$ & $1.33 \mathrm{E}-05$ & 0.6406 & Po212 & 0.3594 & Tl208 \\
\hline
\end{tabular}


SRNL-STI-2013-00394

\begin{tabular}{|c|c|c|c|c|c|}
\hline Radionuclide & $\begin{array}{c}\text { Half-life } \\
\text { (years) }\end{array}$ & $\begin{array}{c}\text { Daughter } 1 \\
\text { Branching } \\
\text { Fraction } \\
\end{array}$ & Daughter 1 & $\begin{array}{c}\text { Daughter } 2 \\
\text { Branching } \\
\text { Fraction } \\
\end{array}$ & Daughter 2 \\
\hline $\mathrm{Bi} 213$ & 8.67E-05 & 0.9791 & Po213 & 0.0209 & Tl209 \\
\hline $\mathrm{Bi} 214$ & 3.78E-05 & 0.99979 & Po214 & 0.00021 & $\mathrm{Tl} 210$ \\
\hline Fr221 & $9.32 \mathrm{E}-06$ & 1 & At217 & & \\
\hline Fr223 & 4.18E-05 & 1 & Ra223 & 1 & \\
\hline Np237 & $2.14 \mathrm{E}+06$ & 1 & $\mathrm{~Pa} 233$ & & \\
\hline $\mathrm{Pa} 231$ & $3.28 \mathrm{E}+04$ & 1 & Ac227 & & \\
\hline Pa233 & 7.38E-02 & 1 & U233 & & \\
\hline $\mathrm{Pa} 234$ & 7.64E-04 & 1 & U234 & & \\
\hline $\mathrm{Pa} 234 \mathrm{~m}$ & 2.22E-06 & 0.9984 & U234 & 0.0016 & $\mathrm{~Pa} 234$ \\
\hline Pb209 & 3.71E-04 & 1 & $B i$ & & \\
\hline Pb210 & $2.22 \mathrm{E}+01$ & 1 & $\mathrm{Bi} 210$ & 1 & \\
\hline $\mathrm{Pb} 211$ & 6.86E-05 & 1 & $\mathrm{Bi} 211$ & & \\
\hline $\mathrm{Pb} 212$ & $1.21 \mathrm{E}-03$ & 1 & $\mathrm{Bi} 212$ & & \\
\hline Pb214 & 5.10E-05 & 1 & $\mathrm{Bi} 214$ & & \\
\hline Po210 & 3.79E-01 & 1 & $\mathrm{~Pb}$ & & \\
\hline Po211 & $1.64 \mathrm{E}-08$ & 1 & $\mathrm{~Pb}$ & & \\
\hline Po212 ${ }^{2}$ & $\begin{array}{r}9.47 \mathrm{E}-15 \\
(2.00 \mathrm{E}-10) \\
\end{array}$ & 1 & $P b$ & & \\
\hline Po213 ${ }^{2}$ & $\begin{array}{r}1.33 \mathrm{E}-13 \\
(2.00 \mathrm{E}-10)\end{array}$ & 1 & Pb209 & & \\
\hline Po214 2 & $\begin{array}{r}5.21 \mathrm{E}-12 \\
(2.00 \mathrm{E}-10) \\
\end{array}$ & 1 & $\mathrm{~Pb} 210$ & & \\
\hline Po215 2 & $\begin{array}{r}5.64 \mathrm{E}-11 \\
(2.00 \mathrm{E}-10) \\
\end{array}$ & 1 & Pb211 & & \\
\hline Po216 & 4.59E-09 & 1 & $\mathrm{~Pb} 212$ & & \\
\hline Po218 & 5.89E-06 & 0.9998 & $\mathrm{~Pb} 214$ & 0.0002 & At218 \\
\hline Pu238 & $8.77 \mathrm{E}+01$ & 1 & U234 & & \\
\hline Pu239 & $2.41 \mathrm{E}+04$ & 0.9994 & $\mathrm{U} 235 \mathrm{~m}$ & 0.0006 & U235 \\
\hline Pu240 & $6.56 \mathrm{E}+03$ & 1 & U236 & & \\
\hline Ra223 & $3.13 E-02$ & 1 & Rn219 & & \\
\hline $\mathrm{Ra} 224$ & $1.00 \mathrm{E}-02$ & 1 & Rn220 & & \\
\hline Ra225 & 4.08E-02 & 1 & Ac225 & & \\
\hline Ra226 & $1.60 \mathrm{E}+03$ & 1 & Rn222 & & \\
\hline Ra228 & $5.75 E+00$ & 1 & Ac228 & & \\
\hline Rn218 & 1.11E-09 & 1 & Po214 & & \\
\hline Rn219 & 1.25E-07 & 1 & Po215 & & \\
\hline Rn220 & $1.76 \mathrm{E}-06$ & 1 & Po216 & & \\
\hline Rn222 & $1.05 \mathrm{E}-02$ & 1 & Po218 & & \\
\hline Tc99 & $2.11 \mathrm{E}+05$ & 1 & $R u$ & & \\
\hline
\end{tabular}


SRNL-STI-2013-00394

\begin{tabular}{|l|r|r|l|l|l|}
\hline Radionuclide & \multicolumn{1}{|c|}{$\begin{array}{c}\text { Half-life } \\
\text { (years) }\end{array}$} & \multicolumn{1}{|c|}{$\begin{array}{l}\text { Daughter 1 } \\
\text { Branching } \\
\text { Fraction }\end{array}$} & Daughter 1 & $\begin{array}{c}\text { Daughter 2 } \\
\text { Branching } \\
\text { Fraction }\end{array}$ & Daughter 2 \\
\hline Th227 & $5.11 \mathrm{E}-02$ & 1 & Ra223 & & \\
\hline Th228 & $1.91 \mathrm{E}+00$ & 1 & Ra224 & & \\
\hline Th229 & $7.34 \mathrm{E}+03$ & 1 & Ra225 & & \\
\hline Th230 & $7.54 \mathrm{E}+04$ & 1 & Ra226 & & \\
\hline Th231 & $2.91 \mathrm{E}-03$ & 1 & Pa231 & & \\
\hline Th232 & $1.41 \mathrm{E}+10$ & 1 & Ra228 & & \\
\hline Th234 & $6.60 \mathrm{E}-02$ & 1 & Pa234m & & \\
\hline T1207 & $9.07 \mathrm{E}-06$ & 1 & Pb & & \\
\hline T1208 & $5.80 \mathrm{E}-06$ & 1 & Pb & & \\
\hline T1209 & $4.11 \mathrm{E}-06$ & 1 & Pb209 & & \\
\hline T1210 & $2.47 \mathrm{E}-06$ & 1 & Pb210 & & \\
\hline U233 & $1.59 \mathrm{E}+05$ & 1 & Th229 & & \\
\hline U234 & $2.46 \mathrm{E}+05$ & 1 & Th230 & & \\
\hline U235 & $7.04 \mathrm{E}+08$ & 1 & Th231 & & \\
\hline U235m & $4.94 \mathrm{E}-05$ & 1 & $\mathrm{U} 235$ & & \\
\hline U236 & $2.34 \mathrm{E}+07$ & 1 & Th232 & & \\
\hline U238 & $4.47 \mathrm{E}+09$ & 1 & Th234 & & \\
\hline
\end{tabular}

Notes to Table 2:

- All data obtained from ICRP 2008

1 Rounded to 1 from value greater than 0.9999; radionuclide dose from other branch insignificant (minor branching fraction less than 0.0001)

2 GoldSim (GTG 2010) does not allow the use of half-lives less than 2.00E-10 years; therefore radionuclides with half-lives less than 2.00E-10 years were set to $2.00 \mathrm{E}-10$ years.

\section{Tc99 $\longrightarrow \mathbb{R u}$}

Figure 2. Technetium-99 Decay to Stable Progeny 


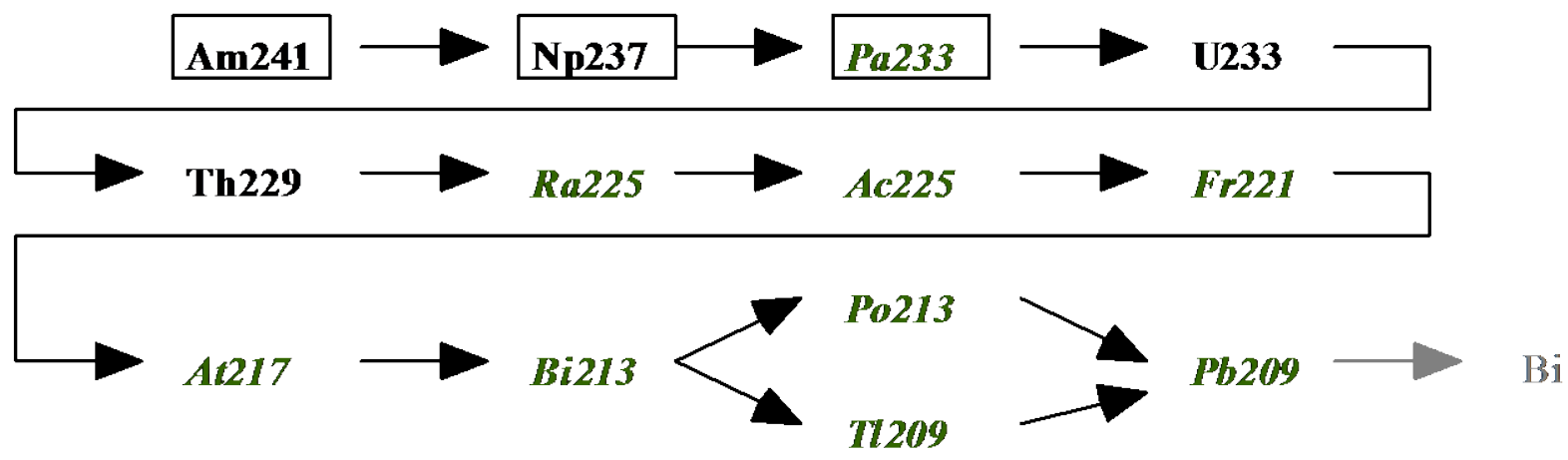

Figure 3. Neptunium Decay Series

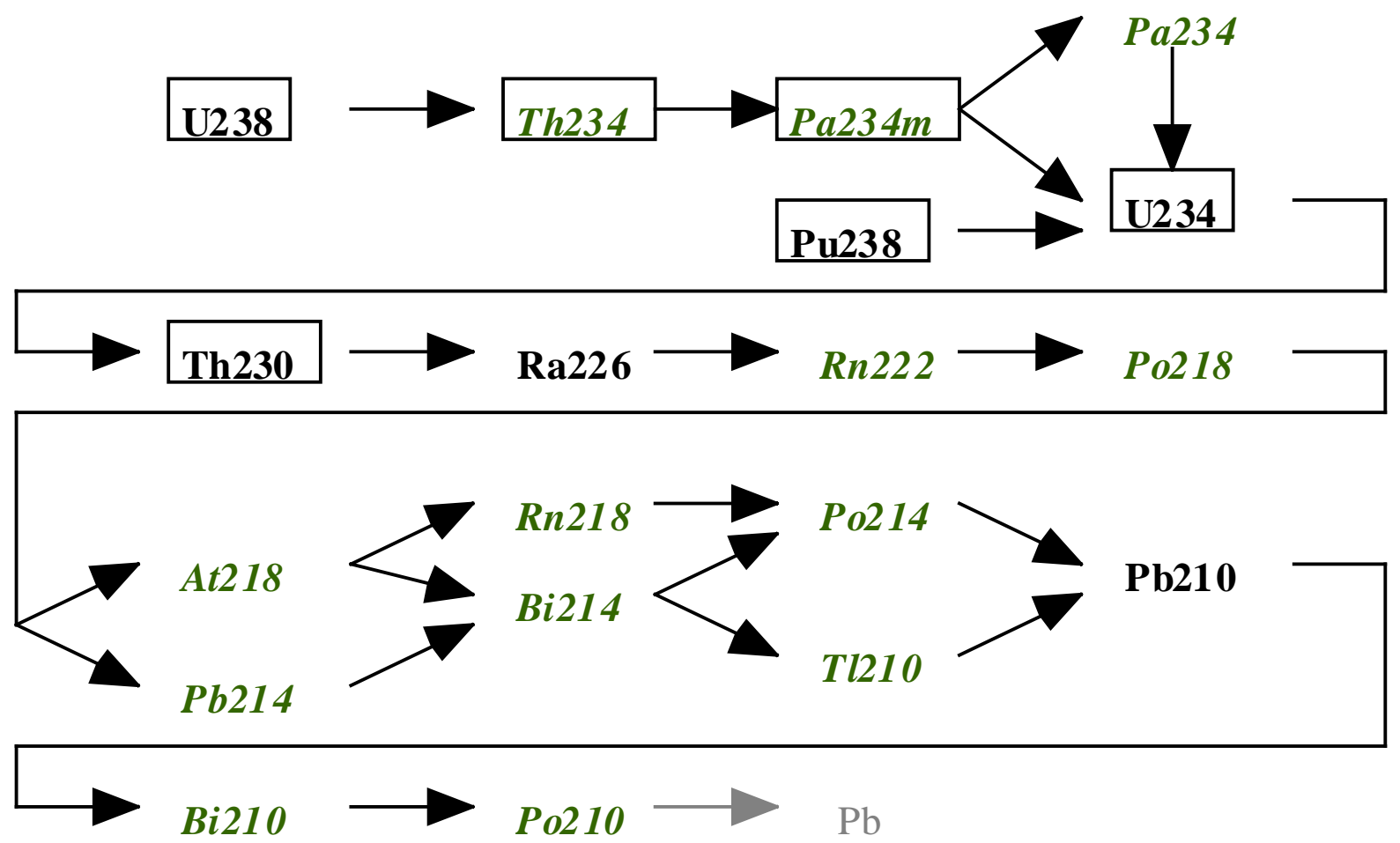

Figure 4. Uranium Decay Series 


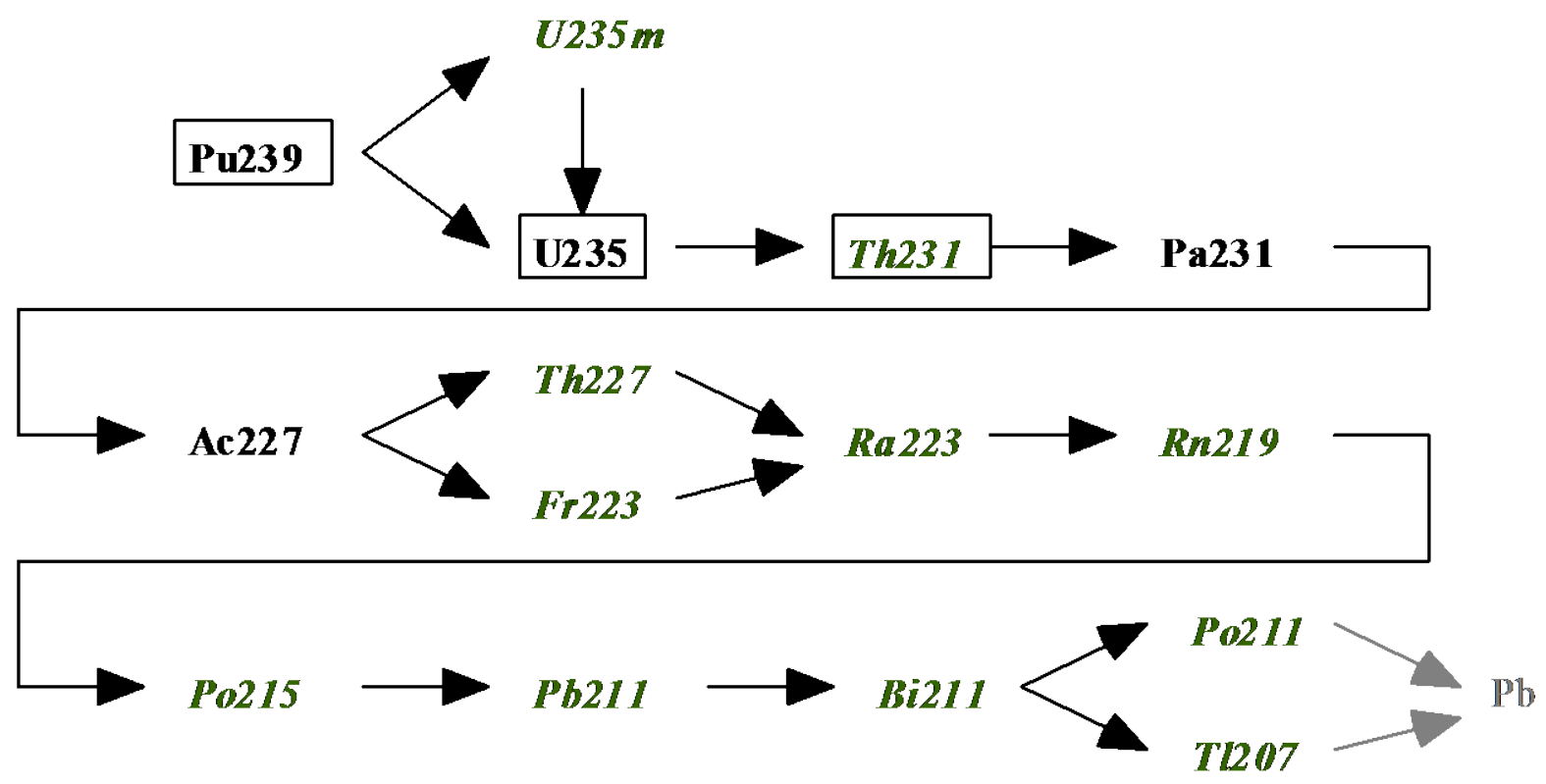

Figure 5. Actinium Decay Series

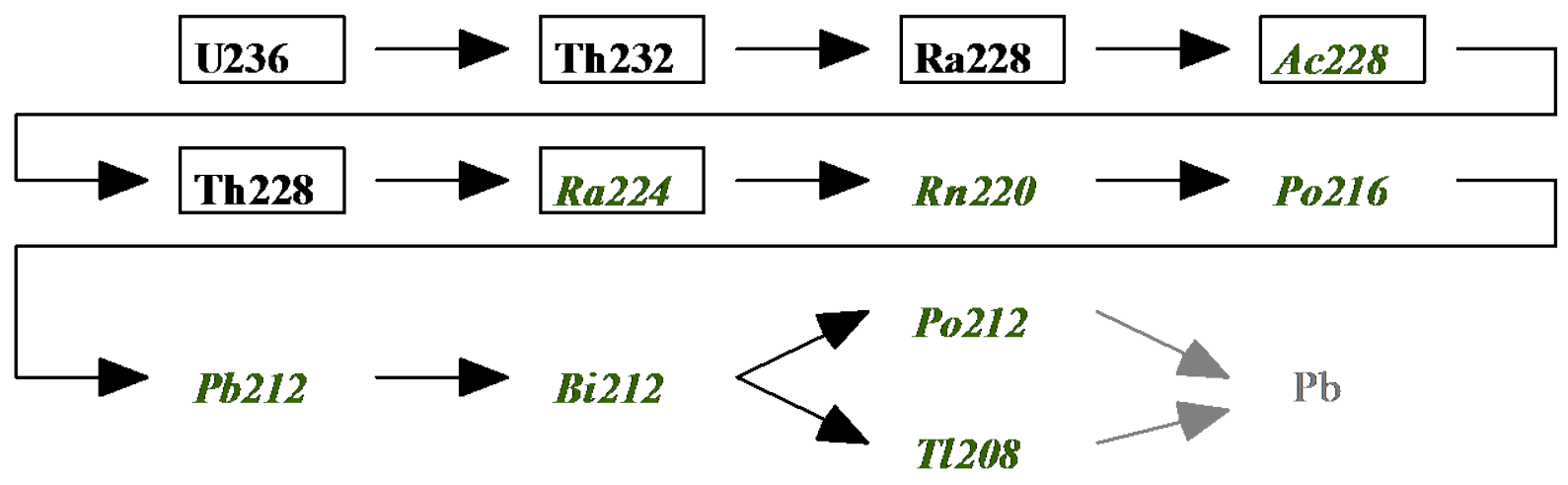

Figure 6. Thorium Decay Series

Notes to Figures 2 through 6:

Radionuclides in bolded black have half-lives greater than 1 yea $r$ Radionuclides in bolded, italtics green have half-lives less than 1 year Radionuclides in a box have a starting OSDC inventoy 


\subsection{MODEL RESULTS}

Figures 7 through 11 provide graphs of the radioactive decay and daughter ingrowth associated with each of the five decay chains (Technetium-99, Neptunium, Uranium, Actinium, and Thorium).

Figure 7 depicts Tc-99 decay. Tc-99 only has the stable Ru-99 isotope as a daughter and is not the progeny of a radioactive parent; so daughter ingrowth is not important for Tc-99 from a radiological perspective.

Figure 8, which depicts the Neptunium decay series, shows that the Pa-233 remains at the activity of its parent Np-237 throughout the 100,000 year period modeled. While Am-241 decays to Np-237, its decay has only a negligible impact on the Np-237 activity over time, because the Am-241 initial inventory is an order of magnitude less than the initial Np-237 inventory. Other daughters of Np-237 have activities at least two orders of magnitude lower than that of Np-237 during the 1,000 year Assessment Period, but these other daughters become more significant relative to Np-237 after 1,000 years for consideration of the peak impact from the OSWDF.

Figure 9, which depicts the Uranium series, shows that Th-234 and Pa-234m remain at the activity of their parent U-238. U-238, Th-234, Pa-234m, and Pu-238 decay to U-234 only has a small impact on the U-234 activity over time. The most significant U-234 daughter during the 1,000 year Assessment Period is Th-230. During the 1,000 year Assessment Period, Th-230 remains at an activity that is approximately a two orders of magnitude less than the U-234. Many of the daughters become more significant relative to their parents after 1,000 years for consideration of the peak impact from the OSWDF.

Figure 10, which depicts the Actinium series, shows that Th-231 remains at the activity of its parent U-235 throughout the 100,000 period modeled. While Pu-239 decays to U-235, its decay has only a negligible impact on the U-235 activity over time, because the Pu-239 initial inventory is approximately three orders of magnitude less than the initial U-235 inventory. The most significant daughters during the 1,000 year Assessment Period are Pa231, Ac-227, Th-227, Ra-223, Rn-219, Po-215, Pb-211, Bi-211, and Tl-207. During the 1,000 year Assessment Period, each of these nine daughters are at an activity that is at least an order of magnitude less than the U-235; however their combined significance could be greater. After the 1,000 year Assessment Period these nine daughters become more significant relative to U-235 for consideration of the peak impact from the OSWDF.

Figure 11 depicts the Thorium series. Throughout the 100,000 year period modeled all eleven daughters of U-236 remain at fairly constant activities that are approximately two orders of magnitude less than that of U-236. The combined activity of the eleven daughters is still approximately one order of magnitude less than that of U-236.

Figures 8 through 11 also point out that daughters with half-lives less than one year often approach secular equilibrium with the closest parent in the series with a half-life greater than 
one year over a very long time frame, often on the order of 10,000 to 100,000 years. This means that the assumption of secular equilibrium within the 1,000 year Assessment Period can often be a very conservative assumption.

Table 3 provides a comparison of the activity of the Table 1 OSWDF inventory radionuclides with and without consideration of daughter ingrowth at 100, 1,000,10,000, and 100,000 years. The radionuclides and times highlighted in yellow indicate that a lack of daughter ingrowth consideration results in an underestimate of the inventory for that OSWDF inventory radionuclide at that time frame. The following are observations associated with Table 3:

- The lack of daughter ingrowth consideration does not impact Tc-99, because it is not a daughter of another OSWDF inventory radionuclide.

- Pa-233 in the Neptunium series shows a significant impact from the lack of daughter ingrowth consideration, because it is a progeny of another OSWDF inventory radionuclide. Pa-233 has a relatively short half-life of 7.4E-02 years. With such a short half-live the initial inventory of Pa-233 is quickly depleted; however, as shown by Figure 8, Pa-233 should be in secular equilibrium with $\mathrm{Np}-237$ and have a fairly continuous inventory of 0.14 Curies.

- Within the Uranium series the radionuclides Th-234, Pa-234m, U-234, and Th-230 do show a significant impact from the lack of daughter ingrowth consideration, because they are progeny of another OSWDF inventory radionuclide. Th-234 and Pa-234m have relatively short half-lives of 6.6E-02 and 2.2E-06 years, respectively. With such short half-lives the initial inventories of these radionuclides are quickly depleted; however, as shown by Figure 9, these radionuclides should be in secular equilibrium with U-238 and have a continuous inventory of 87.6 Curies each. U-234 and Th-230 have relatively long half-lives of $2.5 \mathrm{E}+05$ and $7.5 \mathrm{E}+04$ years, respectively. With such long half-lives the initial inventories of these radionuclides are not depleted within the time frame of concern; however since both of these radionuclides are daughters of other OSWDF inventory radionuclides, the lack of daughter ingrowth consideration results in a greater and greater underestimate of the U-234 and Th-230 inventories over time.

- Within the Actinium series only the Th-231 shows a significant impact from the lack of daughter ingrowth consideration. Th-231 has a relatively short half-live of 2.9E-03 years which results in its initial inventory being quickly depleted. However, as shown by Figure 10, Th-231 should be in secular equilibrium with U-235 and have a continuous inventory of 12.7 Curies.

- Within the Thorium series Ra-228, Ac-228, Th-228, and Ra-224 are greatly impacted by the lack of daughter ingrowth consideration. However, over the 100,000 year period model, as shown in Figure 11, the activities of all these daughters of U-236 remain at least two orders of magnitude below that of U-236. 


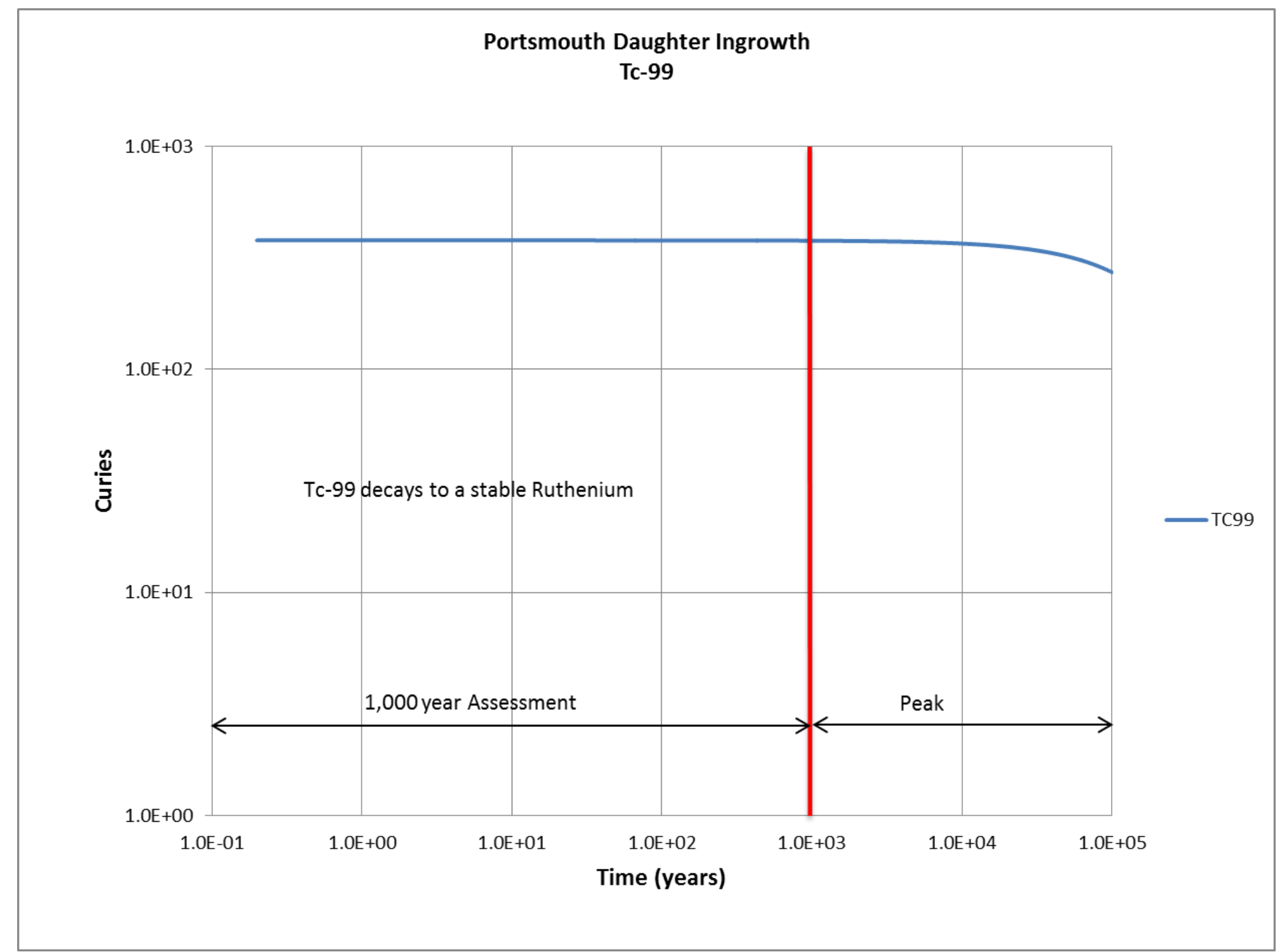

Figure 7. Portsmouth OSWDF Scenario 4 Inventory - Technetium-99 Decay 
Portsmouth Daughter Ingrowth

Neptunium Series
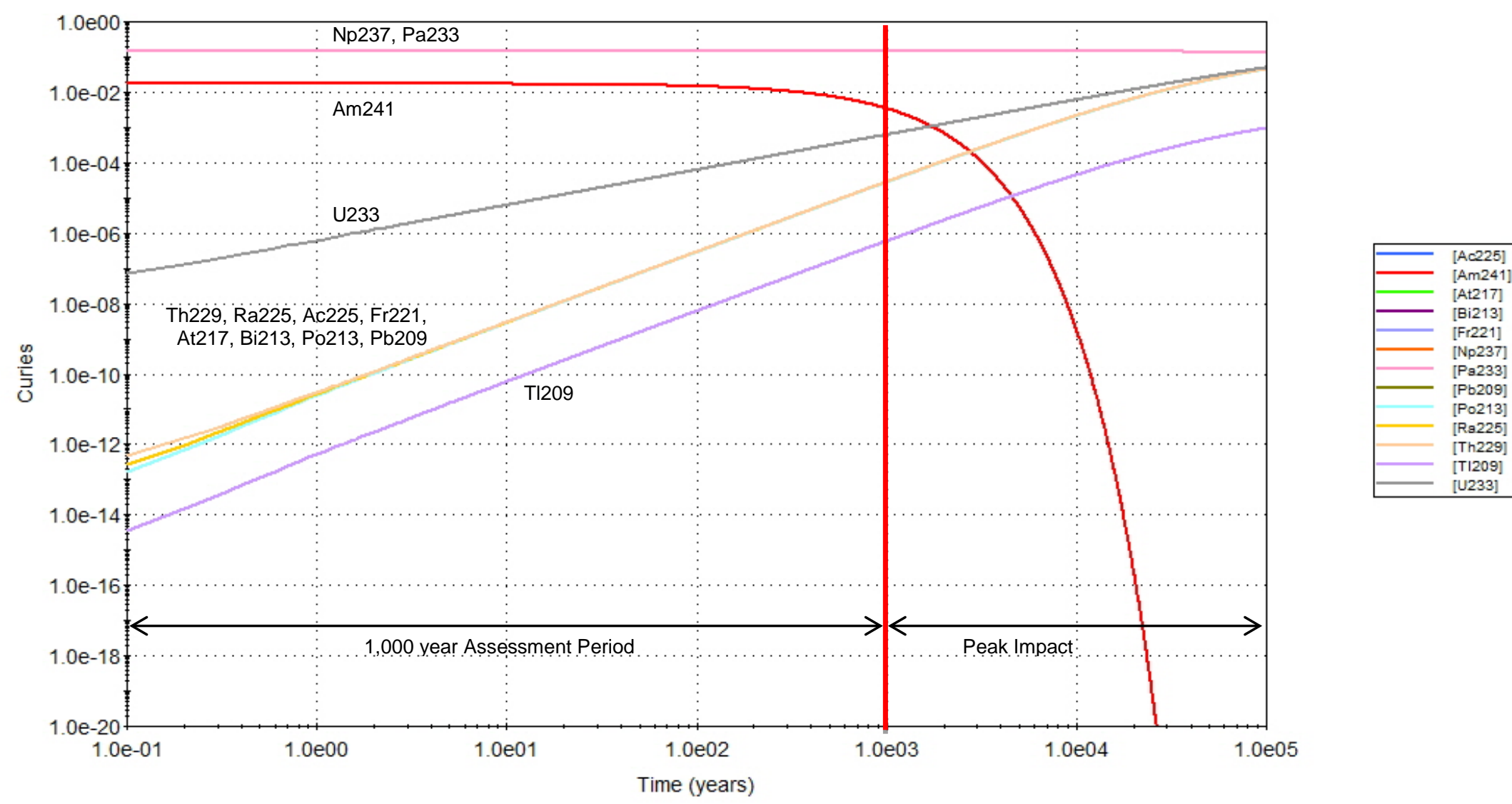

Figure 8. Portsmouth OSWDF Scenario 4 Inventory - Neptunium Decay Series Daughter Ingrowth 
Portsmouth Daughter Ingrowth Uranium Series
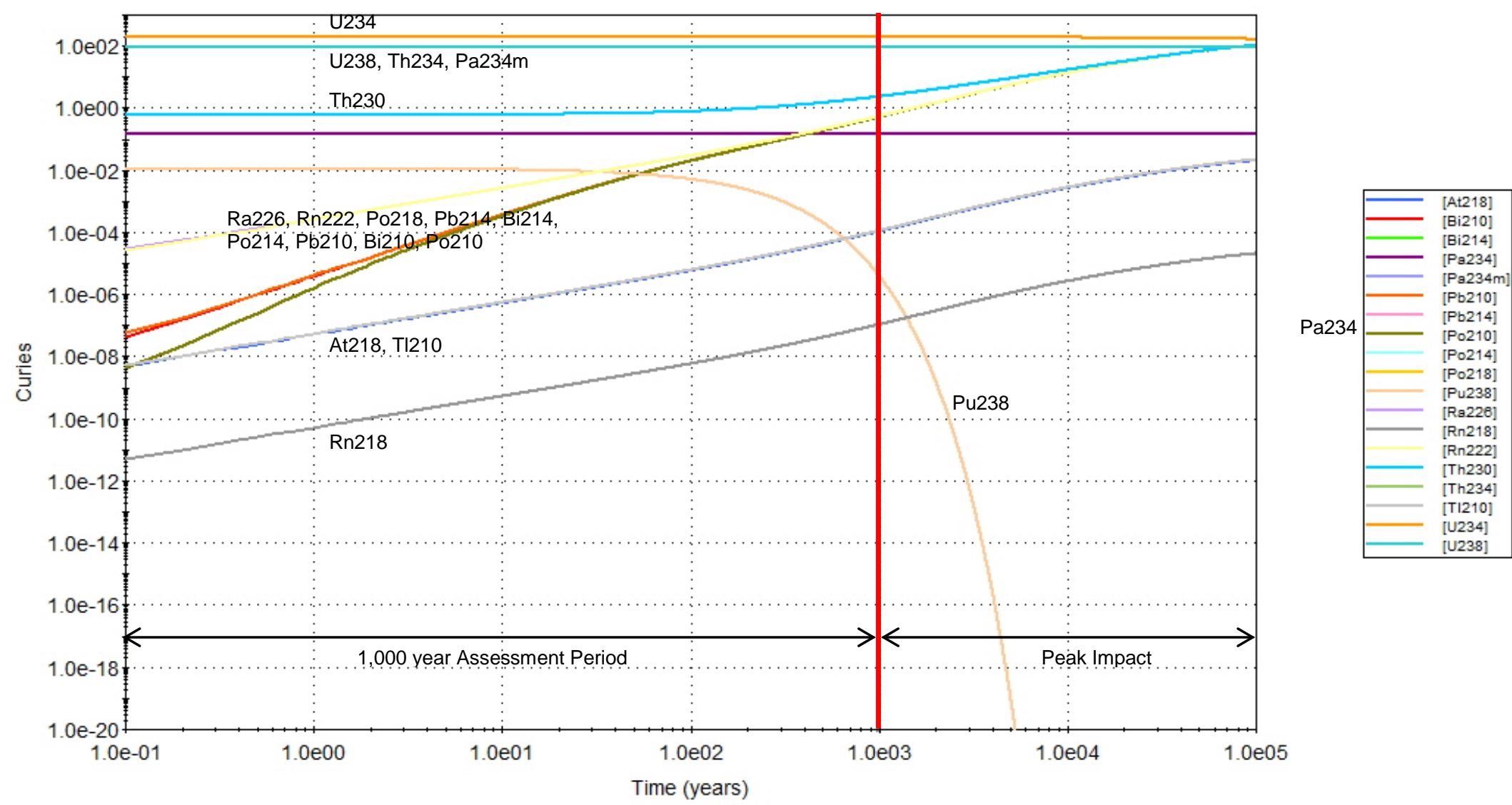

Figure 9. Portsmouth OSWDF Scenario 4 Inventory - Uranium Decay Series Daughter Ingrowth 
Portsmouth Daughter Ingrowth

Actinium Series
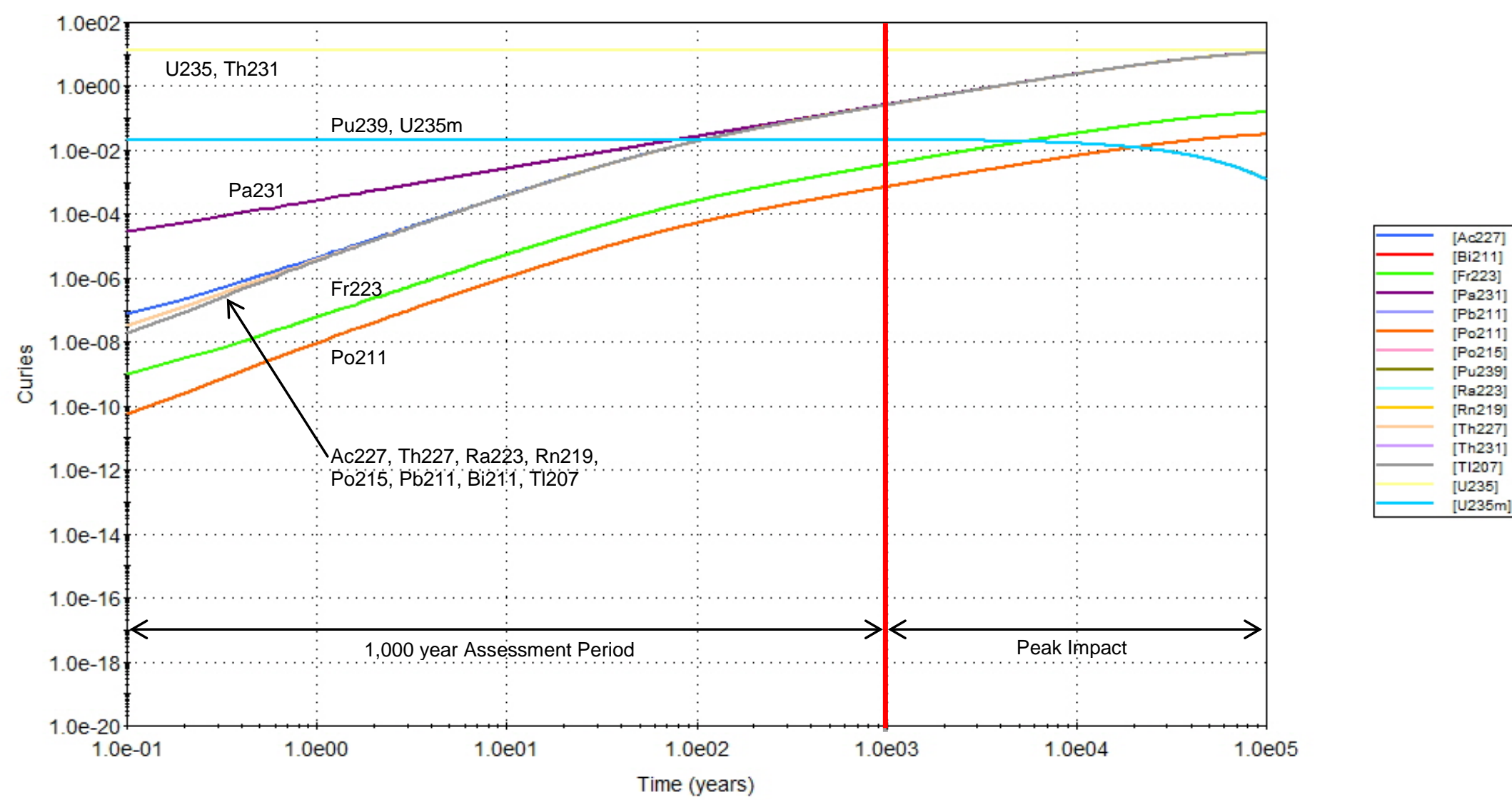

Figure 10. Portsmouth OSWDF Scenario 4 Inventory - Actinium Decay Series Daughter Ingrowth 
Portsmouth Daughter Ingrowth

Thorium Series
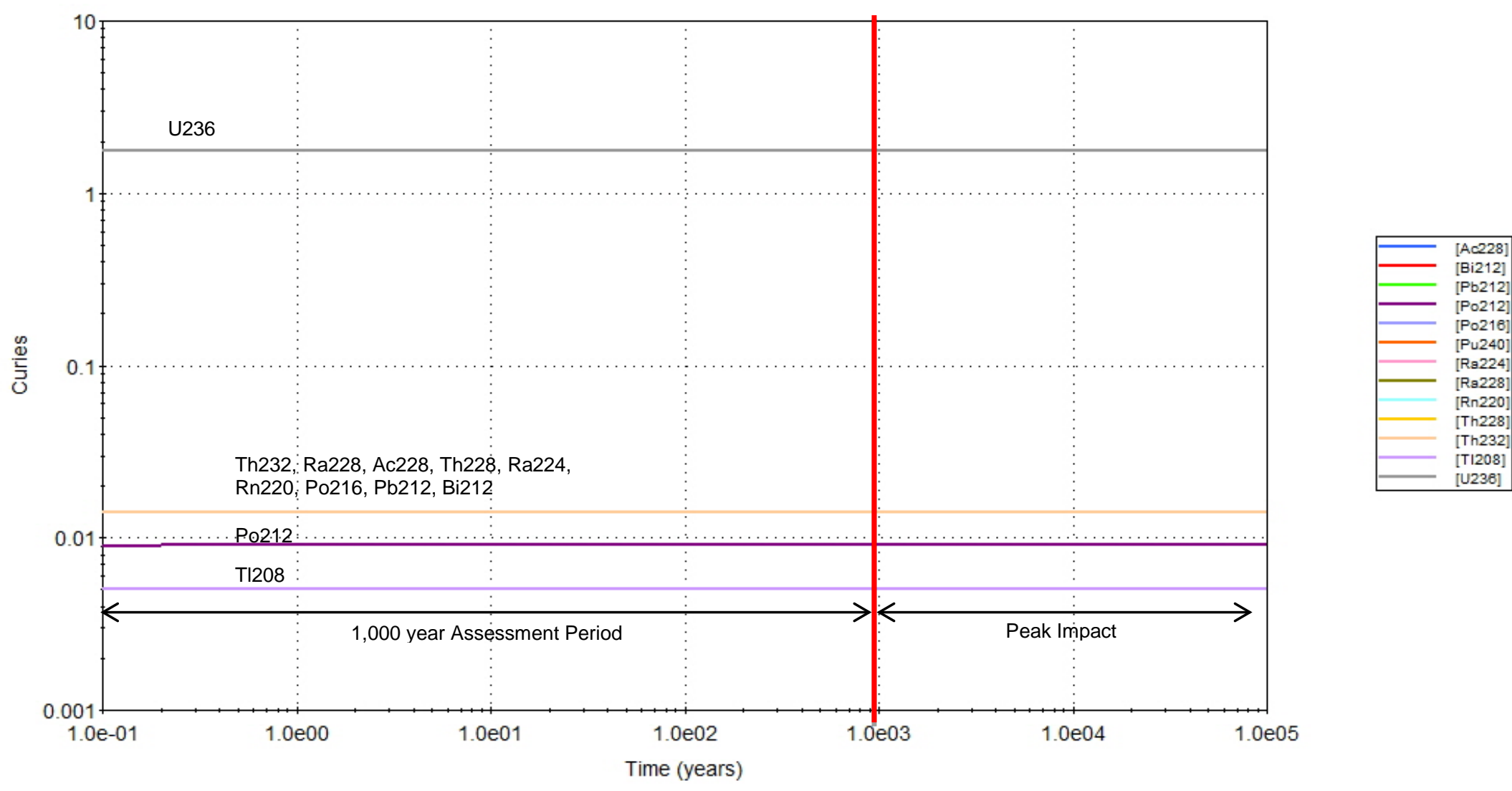

Figure 11. Portsmouth OSWDF Scenario 4 Inventory - Thorium Decay Series Daughter Ingrowth 
Table 3. Portsmouth OSWDF Scenario 4 Inventory - Decay Comparison

\begin{tabular}{|c|c|c|c|c|c|c|c|c|c|c|c|}
\hline $\begin{array}{c}\text { Type of Decay \& } \\
\text { Ingrowth Evaluation }\end{array}$ & $\begin{array}{c}\text { Duration } \\
\text { (years) }\end{array}$ & $\begin{array}{c}\text { Tc99 } \\
\text { (Curies) }\end{array}$ & $\begin{array}{l}\text { Am241 }{ }^{1} \\
\text { (Curies) }\end{array}$ & $\begin{array}{l}\text { Np237 } \\
\text { (Curies) }\end{array}$ & $\begin{array}{c}\text { Pa233 } \\
\text { (Curies) }\end{array}$ & $\begin{array}{c}\text { U238 } \\
\text { (Curies) }\end{array}$ & $\begin{array}{c}\text { Th234 } \\
\text { (Curies) }\end{array}$ & $\begin{array}{l}\text { Pa234m } \\
\text { (Curies) }\end{array}$ & $\begin{array}{l}\text { Pu238 }{ }^{1} \\
\text { (Curies) }\end{array}$ & $\begin{array}{c}\text { U234 } \\
\text { (Curies) }\end{array}$ & $\begin{array}{c}\text { Th230 } \\
\text { (Curies) }\end{array}$ \\
\hline Initial Inventory & 0 & $3.79 \mathrm{E}+02$ & $1.71 \mathrm{E}-02$ & $1.41 \mathrm{E}-01$ & $1.41 \mathrm{E}-01$ & $8.76 \mathrm{E}+01$ & $8.76 \mathrm{E}+01$ & $8.76 \mathrm{E}+01$ & $1.12 \mathrm{E}-02$ & $1.88 \mathrm{E}+02$ & $6.03 \mathrm{E}-01$ \\
\hline Decay & 100 & $3.79 \mathrm{E}+02$ & $1.46 \mathrm{E}-02$ & $1.41 \mathrm{E}-01$ & $0.00 \mathrm{E}+00$ & $8.76 \mathrm{E}+01$ & $0.00 \mathrm{E}+00$ & $0.00 \mathrm{E}+00$ & 5.08E-03 & $1.88 \mathrm{E}+02$ & 6.02E-01 \\
\hline Decay \& Ingrowth & 100 & $3.79 \mathrm{E}+02$ & $1.46 \mathrm{E}-02$ & $1.41 \mathrm{E}-01$ & $1.41 \mathrm{E}-01$ & $8.76 \mathrm{E}+01$ & $8.76 \mathrm{E}+01$ & $8.76 \mathrm{E}+01$ & $5.08 \mathrm{E}-03$ & $1.88 \mathrm{E}+02$ & 7.75E-01 \\
\hline Decay & 1,000 & $3.78 \mathrm{E}+02$ & $3.44 \mathrm{E}-03$ & $1.41 \mathrm{E}-01$ & $0.00 \mathrm{E}+00$ & $8.76 \mathrm{E}+01$ & $0.00 \mathrm{E}+00$ & $0.00 \mathrm{E}+00$ & $4.14 \mathrm{E}-06$ & $1.87 \mathrm{E}+02$ & 5.97E-01 \\
\hline Decay \& Ingrowth & 1,000 & $3.78 \mathrm{E}+02$ & $3.44 \mathrm{E}-03$ & $1.41 \mathrm{E}-01$ & $1.41 \mathrm{E}-01$ & $8.76 \mathrm{E}+01$ & $8.76 \mathrm{E}+01$ & $8.76 \mathrm{E}+01$ & 4.17E-06 & $1.88 \mathrm{E}+02$ & $2.32 \mathrm{E}+00$ \\
\hline Decay & 10,000 & $3.67 \mathrm{E}+02$ & $1.85 \mathrm{E}-09$ & $1.41 \mathrm{E}-01$ & $0.00 \mathrm{E}+00$ & $8.76 \mathrm{E}+01$ & $0.00 \mathrm{E}+00$ & $0.00 \mathrm{E}+00$ & $5.30 \mathrm{E}-37$ & $1.83 \mathrm{E}+02$ & $5.50 \mathrm{E}-01$ \\
\hline Decay \& Ingrowth & 10,000 & $3.67 \mathrm{E}+02$ & 1.89E-09 & $1.41 \mathrm{E}-01$ & $1.41 \mathrm{E}-01$ & $8.76 \mathrm{E}+01$ & $8.76 \mathrm{E}+01$ & $8.76 \mathrm{E}+01$ & $1.07 \mathrm{E}-36$ & $1.85 \mathrm{E}+02$ & $1.69 \mathrm{E}+01$ \\
\hline Decay & 100,000 & $2.73 \mathrm{E}+02$ & 3.82E-72 & $1.37 \mathrm{E}-01$ & $0.00 \mathrm{E}+00$ & $8.76 \mathrm{E}+01$ & $0.00 \mathrm{E}+00$ & $0.00 \mathrm{E}+00$ & $0.00 \mathrm{E}+00$ & $1.42 \mathrm{E}+02$ & $2.40 \mathrm{E}-01$ \\
\hline Decay \& Ingrowth & 100,000 & $2.73 \mathrm{E}+02$ & $0.00 \mathrm{E}+00$ & $1.37 \mathrm{E}-01$ & $1.37 \mathrm{E}-01$ & $8.76 \mathrm{E}+01$ & $8.76 \mathrm{E}+01$ & $8.76 \mathrm{E}+01$ & $0.00 \mathrm{E}+00$ & $1.63 \mathrm{E}+02$ & $1.04 \mathrm{E}+02$ \\
\hline $\begin{array}{c}\text { Type of Decay \& } \\
\text { Ingrowth Evaluation }\end{array}$ & $\begin{array}{c}\text { Duration } \\
\text { (years) }\end{array}$ & $\begin{array}{c}\text { Pu239 } \\
\text { (Curies) }\end{array}$ & $\begin{array}{c}\text { U235 } \\
\text { (Curies) }\end{array}$ & $\begin{array}{l}\text { Th231 } \\
\text { (Curies) }\end{array}$ & $\begin{array}{c}\text { U236 } \\
\text { (Curies) }\end{array}$ & $\begin{array}{c}\text { Th232 } \\
\text { (Curies) }\end{array}$ & $\begin{array}{c}\text { Ra228 } \\
\text { (Curies) }\end{array}$ & $\begin{array}{c}\text { Ac228 } \\
\text { (Curies) }\end{array}$ & $\begin{array}{l}\text { Th228 } \\
\text { (Curies) }\end{array}$ & $\begin{array}{c}\text { Ra224 } \\
\text { (Curies) }\end{array}$ & \\
\hline Initial Inventory & 0 & $2.17 \mathrm{E}-02$ & $1.27 \mathrm{E}+01$ & $1.27 \mathrm{E}+01$ & $1.78 \mathrm{E}+00$ & $1.41 \mathrm{E}-02$ & $1.41 \mathrm{E}-02$ & $1.41 \mathrm{E}-02$ & $1.41 \mathrm{E}-02$ & $1.41 \mathrm{E}-02$ & \\
\hline Decay & 100 & $2.16 \mathrm{E}-02$ & $1.27 \mathrm{E}+01$ & $0.00 \mathrm{E}+00$ & $1.78 \mathrm{E}+00$ & $1.41 \mathrm{E}-02$ & $8.20 \mathrm{E}-08$ & $0.00 \mathrm{E}+00$ & $2.52 \mathrm{E}-18$ & $0.00 \mathrm{E}+00$ & \\
\hline Decay \& Ingrowth & 100 & $2.16 \mathrm{E}-02$ & $1.27 \mathrm{E}+01$ & $1.27 \mathrm{E}+01$ & $1.78 \mathrm{E}+00$ & $1.41 \mathrm{E}-02$ & $1.41 \mathrm{E}-02$ & $1.41 \mathrm{E}-02$ & $1.41 \mathrm{E}-02$ & $1.41 \mathrm{E}-02$ & \\
\hline Decay & 1,000 & $2.11 \mathrm{E}-02$ & $1.27 \mathrm{E}+01$ & $0.00 \mathrm{E}+00$ & $1.78 \mathrm{E}+00$ & $1.41 \mathrm{E}-02$ & $6.25 \mathrm{E}-55$ & $0.00 \mathrm{E}+00$ & $4.72 \mathrm{E}-160$ & $0.00 \mathrm{E}+00$ & \\
\hline Decay \& Ingrowth & 1,000 & $2.11 \mathrm{E}-02$ & $1.27 \mathrm{E}+01$ & $1.27 \mathrm{E}+01$ & $1.78 \mathrm{E}+00$ & $1.41 \mathrm{E}-02$ & $1.41 \mathrm{E}-02$ & $1.41 \mathrm{E}-02$ & $1.41 \mathrm{E}-02$ & $1.41 \mathrm{E}-02$ & \\
\hline Decay & 10,000 & $1.63 \mathrm{E}-02$ & $1.27 \mathrm{E}+01$ & $0.00 \mathrm{E}+00$ & $1.78 \mathrm{E}+00$ & $1.41 \mathrm{E}-02$ & $0.00 \mathrm{E}+00$ & $0.00 \mathrm{E}+00$ & $0.00 \mathrm{E}+00$ & $0.00 \mathrm{E}+00$ & \\
\hline Decay \& Ingrowth & 10,000 & $1.63 \mathrm{E}-02$ & $1.27 \mathrm{E}+01$ & $1.27 \mathrm{E}+01$ & $1.78 \mathrm{E}+00$ & $1.41 \mathrm{E}-02$ & $1.41 \mathrm{E}-02$ & $1.41 \mathrm{E}-02$ & $1.41 \mathrm{E}-02$ & $1.41 \mathrm{E}-02$ & \\
\hline Decay & 100,000 & $1.22 \mathrm{E}-03$ & $1.27 \mathrm{E}+01$ & $0.00 \mathrm{E}+00$ & $1.77 \mathrm{E}+00$ & $1.41 \mathrm{E}-02$ & $0.00 \mathrm{E}+00$ & $0.00 \mathrm{E}+00$ & $0.00 \mathrm{E}+00$ & $0.00 \mathrm{E}+00$ & \\
\hline Decay \& Ingrowth & 100,000 & $1.22 \mathrm{E}-03$ & $1.27 \mathrm{E}+01$ & $1.27 \mathrm{E}+01$ & $1.77 \mathrm{E}+00$ & $1.41 \mathrm{E}-02$ & $1.41 \mathrm{E}-02$ & $1.41 \mathrm{E}-02$ & $1.41 \mathrm{E}-02$ & $1.41 \mathrm{E}-02$ & \\
\hline
\end{tabular}

Notes to Table 3:

1 Differences in Am-241 and Pu-238 are simply differences in round off protocol between Excel (decay) and GoldSim (decay and ingrowth)

- Radionuclides highlighted in yellow have significant differences between calculations taking into account decay only versus consideration of both decay and daughter ingrowth. While Ra-228, Ac-228, Th-228, and Ra-224 have significance individual differences between calculations taking into account decay only versus consideration of both decay and daughter ingrowth, these radionuclides have little activity importance over the 100,000 year period modeled relative to the other radionuclides. 
SRNL-STI-2013-00394

\subsection{MODEL RESULTS SUMMARY AND CONCLUSIONS}

The following provide a summary of the conclusion drawn from this analysis of daughter ingrowth:

- $\quad$ Tc-99 is the radionuclide with the greatest anticipated OSWDF inventory (i.e. 373 Curies for OSWDF Inventory Scenario 4), and it is not impacted by the lack of daughter ingrowth consideration.

- The Uranium series has anticipated inventories of 87.6 Curies each for U-238, Th234, and Pa-234m and an anticipated inventory of 188 Curies for U-234 based upon the OSWDF Inventory Scenario 4. The lack of daughter ingrowth consideration for the Uranium series can potentially have a significant impact to the subsequent dose calculation. In particular, the lack of daughter ingrowth consideration can lead to significant underestimates associated with the activities of Th-234, Pa-234m, U-234, and Th-230.

- While daughters in the Neptunium, Actinium, and Thorium series can be relatively significant relative to their parents, their overall significance is less than that of the Uranium series due to their lower initial inventories.

- The significance of daughters overall becomes even more significant after 1,000 years for consideration of the peak impact from the OSWDF.

- Distribution coefficients $\left(\mathrm{K}_{\mathrm{d}} \mathrm{s}\right)$, which impact transport to the point of assessment and the resulting concentration with time profile, were not evaluated herein. However the lack of $\mathrm{K}_{\mathrm{d}}$ consideration in the evaluation is considered conservative. This evaluation assumes that all daughters arrive at the point of assessment with the parent (8 radionuclides considered parents) based upon ingrowth alone. This is considered a realistic assumption for all daughters with half-lives less than one year (i.e. 41 of the 61 radionuclides), because within the slow flow transport, geologic environment of the OSWDF such short-lived daughters could not migrate very far from the parent. Daughters with half-lives greater than one year (i.e. only 12 of the 61 radionuclides) could potentially migrate either faster or slower than the parent depending upon the differences in $\mathrm{K}_{\mathrm{d}} \mathrm{S}$, resulting in a different daughter concentration at the point of assessment for any point in time than based upon ingrowth alone. Such a consideration of $K_{d} s$ would most likely result in the peaks of the parents and daughters being separated in time resulting in a lower overall peak than would be calculated based upon ingrowth alone.

- Dose coefficients, which impact dose calculations, were not evaluated herein and could influence which radionuclides are considered insignificant.

\subsection{RECOMMENDATION}

Based upon consultation with Rich Abitz, ratios for daughters at the point of assessment have been developed based on the daughter ingrowth analysis outlined above for each of the decay series with radioactive progeny (Technetium-99, Neptunium, Uranium, Actinium, and Thorium). As stated above, this ratio method does not take into consideration the impact of transport on the concentrations. 
Technetium-99 Decay: The activity concentration of Tc-99 at each time step at the appropriate point of assessment can be appropriately modeled within the OSWDF STOMP model, without the consideration of daughter ingrowth.

Neptunium Decay Series: Table 4 presents the Neptunium decay series daughter to parent ratios developed from the GoldSim decay and daughter ingrowth analysis (see Figure 8). The activity concentration of radionuclides in the Neptunium decay series can be determined as follows:

- The activity concentration of Am-241 and Np-237 at each time step at the appropriate point of assessment can be appropriately modeled within the OSWDF STOMP model, without the consideration of daughter ingrowth.

- The concentration of Pa-233, U-233, Th-229, and Tl-209 at each time step at the point of assessment can be obtained by multiplying the respective Table 4 ratio by the Np-237 concentration at each time step at the point of assessment.

- The concentration of Ra-225, Ac-225, Fr-221, At-217, Bi-213, Po-213, and Pb-209 at each time step at the point of assessment can be obtained by multiplying the Table 4 Th229/Np237 ratio by the Np-237 concentration at each time step at the point of assessment.

Uranium Decay Series: Table 5 presents the Uranium decay series daughter to parent ratios developed from the GoldSim decay and daughter ingrowth analysis (see Figure 9). The activity concentration of radionuclides in the Uranium decay series can be determined as follows:

- The activity concentration of U-238 and Pu-238 at each time step at the appropriate point of assessment can be appropriately modeled within the OSWDF STOMP model, without the consideration of daughter ingrowth.

- The concentration of Th-234, U234, Pa-234, Th-230, Ra-226, Tl-210, and Rn218 at each time step at the point of assessment can be obtained by multiplying the respective Table 5 ratio by the $U-238$ concentration at each time step at the point of assessment.

- The concentration of Pa-234m at each time step at the point of assessment can be obtained by multiplying the Table 5 Th234/U238 ratio by the U-238 concentration at each time step at the point of assessment.

- The concentration of Rn-222, Po-218, Pb-214, Bi-214, Po-214, Pb-210, Bi-210, and Po-210 at each time step at the point of assessment can be obtained by multiplying the Table $5 \mathrm{Ra} 226 / \mathrm{U} 238$ ratio by the U-238 concentration at each time step at the point of assessment.

- The concentration of At218 at each time step at the point of assessment can be obtained by multiplying the Table $5 \mathrm{Tl} 210 / \mathrm{U} 238$ ratio by the U-238 concentration at each time step at the point of assessment.

Actinium Decay Series: Table 6 presents the Actinium decay series daughter to parent ratios developed from the GoldSim decay and daughter ingrowth analysis (see Figure 10). The activity concentration of radionuclides in the Actinium decay series can be determined as follows: 
- The activity concentration of Pu-239 and U-235 at each time step at the appropriate point of assessment can be appropriately modeled within the OSWDF STOMP model, without the consideration of daughter ingrowth.

- The concentration of U-235m at each time step at the point of assessment can be obtained by multiplying the Table $6 \mathrm{U} 235 \mathrm{~m} / \mathrm{U} 239$ ratio by the U-239 concentration at each time step at the point of assessment.

- The concentration of Th-231, Pa-231, Fr-223, and Po-211 at each time step at the point of assessment can be obtained by multiplying the respective Table 6 ratio by the U-235 concentration at each time step at the point of assessment.

- The concentration of Ac-227, Th-227, Ra-223, Rn-219, Po-215, Pb-211, Bi-211, and Tl-207 at each time step at the point of assessment can be obtained by multiplying the Table $6 \mathrm{~Pa} 231 / \mathrm{U} 235$ ratio by the U-235 concentration at each time step at the point of assessment.

Thorium Decay Series: Table 7 presents the Thorium decay series daughter to parent ratios developed from the GoldSim decay and daughter ingrowth analysis (see Figure 11). The activity concentration of radionuclides in the Thorium decay series can be determined as follows:

- The activity concentration of U-236 at each time step at the appropriate point of assessment can be appropriately modeled within the OSWDF STOMP model, without the consideration of daughter ingrowth.

- The concentration of Th232, Po212, and Tl208 at each time step at the point of assessment can be obtained by multiplying the respective Table 7 ratio by the U-236 concentration at each time step at the point of assessment.

- The concentration of Ra-228, Ac-228, Th-228, Ra-224, Rn-220, Po-216, Pb-212, and $\mathrm{Bi}-212$ at each time step at the point of assessment can be obtained by multiplying the Table 7 Th232/u236 ratio by the U-236 concentration at each time step at the point of assessment.

In summary the activity concentration of Tc-99, Am-241, Np-237, U-238, Pu-238, Pu-239, U-235, and U-236 at each time step at the appropriate point of assessment can be appropriately modeled within the OSWDF STOMP model, without the consideration of daughter ingrowth. The activity concentration of the remaining radionuclides can be obtained at each time step at the point of assessment by multiplying the appropriate ratio from Tables 7, 8, 9, and 10 as outlined above.

During the 1,000 year Assessment Period the following radionuclides, in order of activity importance, will have a significant activity relative to the radionuclides which can be appropriately modeled within the OSWDF STOMP model (see paragraph above): U-234, Th234, Pa-234m, U-235m, Th-231, and Pa-233. The impact of daughter ingrowth on the concentration of these radionuclides at the point of assessment should be considered as outlined above. After the 1,000 year Assessment Period, for consideration of peak impact, the following additional radionuclides, in order of activity importance, will have a significant activity: Th230, Ra-226, Pa-231, U-233, and Th-229 and should also be considered at least in relation to peak impact. The remaining radionuclides (see Table 8 for a list of these radionuclides) have little activity importance over the 100,000 year period modeled, and the 
analysis documented herein could potentially be used to discount these radionuclides from further consideration. However this analysis does not factor in the impact of dose coefficients on the dose significance of these radionuclides, which might have some bearing on which radionuclides are considered insignificant.

Table 4. Neptunium Decay Series Daughter to Parent Ratios

\begin{tabular}{|c|c|c|c|c|}
\hline $\begin{array}{l}\text { Time } \\
\text { (year) }\end{array}$ & $\begin{array}{c}\text { Pa233/Np237 } \\
\text { Ratio }\end{array}$ & $\begin{array}{c}\text { U233/Np237 } \\
\text { Ratio }\end{array}$ & $\begin{array}{c}\text { Th229/Np237 } \\
\text { Ratio }\end{array}$ & $\begin{array}{c}\text { Tl209/Np237 } \\
\text { Ratio }\end{array}$ \\
\hline 0 & 1 & 0 & 0 & 0 \\
\hline 50 & 1 & $2.18 \mathrm{E}-04$ & 5.14E-07 & 1.07E-08 \\
\hline 100 & 1 & $4.36 \mathrm{E}-04$ & $2.05 \mathrm{E}-06$ & $4.28 \mathrm{E}-08$ \\
\hline 200 & 1 & 8.72E-04 & 8.19E-06 & $1.71 \mathrm{E}-07$ \\
\hline 300 & 1 & $1.31 \mathrm{E}-03$ & 1.84E-05 & 3.83E-07 \\
\hline 400 & 1 & $1.74 \mathrm{E}-03$ & 3.25E-05 & 6.79E-07 \\
\hline 500 & 1 & $2.18 \mathrm{E}-03$ & $5.06 \mathrm{E}-05$ & $1.06 \mathrm{E}-06$ \\
\hline 510 & 1 & $2.22 \mathrm{E}-03$ & $5.27 \mathrm{E}-05$ & $1.10 \mathrm{E}-06$ \\
\hline 520 & 1 & $2.26 \mathrm{E}-03$ & $5.47 \mathrm{E}-05$ & $1.14 \mathrm{E}-06$ \\
\hline 530 & 1 & $2.31 \mathrm{E}-03$ & 5.69E-05 & 1.19E-06 \\
\hline 540 & 1 & $2.35 \mathrm{E}-03$ & $5.90 \mathrm{E}-05$ & $1.23 \mathrm{E}-06$ \\
\hline 550 & 1 & $2.40 \mathrm{E}-03$ & $6.12 \mathrm{E}-05$ & $1.28 \mathrm{E}-06$ \\
\hline 560 & 1 & $2.44 \mathrm{E}-03$ & 6.34E-05 & $1.32 \mathrm{E}-06$ \\
\hline 570 & 1 & $2.48 \mathrm{E}-03$ & 6.57E-05 & 1.37E-06 \\
\hline 580 & 1 & $2.53 \mathrm{E}-03$ & $6.80 \mathrm{E}-05$ & $1.42 \mathrm{E}-06$ \\
\hline 590 & 1 & $2.57 \mathrm{E}-03$ & 7.03E-05 & $1.47 \mathrm{E}-06$ \\
\hline 600 & 1 & $2.61 \mathrm{E}-03$ & 7.27E-05 & $1.52 \mathrm{E}-06$ \\
\hline 650 & 1 & 2.83E-03 & 8.52E-05 & $1.78 \mathrm{E}-06$ \\
\hline 700 & 1 & 3.05E-03 & 9.86E-05 & $2.06 \mathrm{E}-06$ \\
\hline 750 & 1 & $3.26 \mathrm{E}-03$ & 1.13E-04 & $2.36 \mathrm{E}-06$ \\
\hline 800 & 1 & $3.48 \mathrm{E}-03$ & $1.28 \mathrm{E}-04$ & $2.68 \mathrm{E}-06$ \\
\hline 850 & 1 & $3.70 \mathrm{E}-03$ & 1.45E-04 & 3.02E-06 \\
\hline 900 & 1 & $3.92 \mathrm{E}-03$ & 1.62E-04 & $3.38 \mathrm{E}-06$ \\
\hline 1,000 & 1 & 4.35E-03 & 1.99E-04 & $4.16 \mathrm{E}-06$ \\
\hline 2,000 & 1 & $8.68 \mathrm{E}-03$ & 7.72E-04 & $1.61 \mathrm{E}-05$ \\
\hline 3,000 & 1 & $1.30 \mathrm{E}-02$ & $1.68 \mathrm{E}-03$ & 3.52E-05 \\
\hline 4,000 & 1 & $1.73 \mathrm{E}-02$ & $2.90 \mathrm{E}-03$ & 6.06E-05 \\
\hline 5,000 & 1 & $2.16 \mathrm{E}-02$ & $4.40 \mathrm{E}-03$ & 9.19E-05 \\
\hline 6,000 & 1 & $2.58 \mathrm{E}-02$ & $6.14 \mathrm{E}-03$ & $1.28 \mathrm{E}-04$ \\
\hline 7,000 & 1 & $3.01 \mathrm{E}-02$ & 8.11E-03 & $1.70 \mathrm{E}-04$ \\
\hline 8,000 & 1 & $3.43 \mathrm{E}-02$ & 1.03E-02 & $2.15 \mathrm{E}-04$ \\
\hline 9,000 & 1 & $3.85 \mathrm{E}-02$ & 1.27E-02 & $2.64 \mathrm{E}-04$ \\
\hline
\end{tabular}


SRNL-STI-2013-00394

\begin{tabular}{|r|r|r|r|r|}
\hline $\begin{array}{c}\text { Time } \\
\text { (year) }\end{array}$ & $\begin{array}{c}\text { Pa233/Np237 } \\
\text { Ratio }\end{array}$ & $\begin{array}{c}\text { U233/Np237 } \\
\text { Ratio }\end{array}$ & $\begin{array}{c}\text { Th229/Np237 } \\
\text { Ratio }\end{array}$ & $\begin{array}{c}\text { Tl209/Np237 } \\
\text { Ratio }\end{array}$ \\
\hline 10,000 & 1 & $4.27 \mathrm{E}-02$ & $1.52 \mathrm{E}-02$ & $3.17 \mathrm{E}-04$ \\
\hline 20,000 & 1 & $8.38 \mathrm{E}-02$ & $4.67 \mathrm{E}-02$ & $9.75 \mathrm{E}-04$ \\
\hline 30,000 & 1 & $1.23 \mathrm{E}-01$ & $8.35 \mathrm{E}-02$ & $1.74 \mathrm{E}-03$ \\
\hline 40,000 & 1 & $1.61 \mathrm{E}-01$ & $1.21 \mathrm{E}-01$ & $2.54 \mathrm{E}-03$ \\
\hline 50,000 & 1 & $1.97 \mathrm{E}-01$ & $1.59 \mathrm{E}-01$ & $3.32 \mathrm{E}-03$ \\
\hline 60,000 & 1 & $2.32 \mathrm{E}-01$ & $1.95 \mathrm{E}-01$ & $4.08 \mathrm{E}-03$ \\
\hline 70,000 & 1 & $2.66 \mathrm{E}-01$ & $2.30 \mathrm{E}-01$ & $4.81 \mathrm{E}-03$ \\
\hline 80,000 & 1 & $2.98 \mathrm{E}-01$ & $2.64 \mathrm{E}-01$ & $5.52 \mathrm{E}-03$ \\
\hline 90,000 & 1 & $3.29 \mathrm{E}-01$ & $2.96 \mathrm{E}-01$ & $6.19 \mathrm{E}-03$ \\
\hline 100,000 & 1 & $3.59 \mathrm{E}-01$ & $3.27 \mathrm{E}-01$ & $6.84 \mathrm{E}-03$ \\
\hline
\end{tabular}

Notes to Table 4:

1. Model Am-241 and Np-237 in the OSWDF STOMP model (decay only) to the point of assessment.

2. Multiply ratios at appropriate times by the $\mathrm{Np}-237$ concentration at the point of assessment to obtain the concentration of that radionuclide at the point of assessment.

3. The ratios for Ra-225, Ac-225, Fr-221, At-217, Bi-213, Po-213, and Pb-209 are the same as that of Th-229.

4. Data provided at times consistent with the time steps utilized within the OSWDF STOMP modeling (Lu 2013).

Table 5. Uranium Decay Series Daughter to Parent Ratios

\begin{tabular}{|r|r|r|r|r|r|r|r|}
\hline $\begin{array}{c}\text { Time } \\
\text { (year) }\end{array}$ & $\begin{array}{c}\text { Th234/U238 } \\
\text { Ratio }\end{array}$ & $\begin{array}{c}\text { U234/U238 } \\
\text { Ratio }\end{array}$ & $\begin{array}{c}\text { Pa234/U238 } \\
\text { Ratio }\end{array}$ & $\begin{array}{c}\text { Th230/U238 } \\
\text { Ratio }\end{array}$ & $\begin{array}{c}\text { Ra226/U238 } \\
\text { Ratio }\end{array}$ & $\begin{array}{c}\text { Tl210/U238 } \\
\text { Ratio }\end{array}$ & $\begin{array}{c}\text { Rn218/U238 } \\
\text { Ratio }\end{array}$ \\
\hline 0 & 1 & 2.15 & 0 & $6.88 \mathrm{E}-03$ & 0 & 0 & 0 \\
\hline 50 & 1 & 2.15 & $1.60 \mathrm{E}-03$ & $7.87 \mathrm{E}-03$ & $1.58 \mathrm{E}-04$ & $3.32 \mathrm{E}-08$ & $3.16 \mathrm{E}-11$ \\
\hline 100 & 1 & 2.15 & $1.60 \mathrm{E}-03$ & $8.85 \mathrm{E}-03$ & $3.34 \mathrm{E}-04$ & $7.01 \mathrm{E}-08$ & $6.68 \mathrm{E}-11$ \\
\hline 200 & 1 & 2.15 & $1.60 \mathrm{E}-03$ & $1.08 \mathrm{E}-02$ & $7.37 \mathrm{E}-04$ & $1.55 \mathrm{E}-07$ & $1.47 \mathrm{E}-10$ \\
\hline 300 & 1 & 2.15 & $1.60 \mathrm{E}-03$ & $1.28 \mathrm{E}-02$ & $1.21 \mathrm{E}-03$ & $2.53 \mathrm{E}-07$ & $2.41 \mathrm{E}-10$ \\
\hline 400 & 1 & 2.14 & $1.60 \mathrm{E}-03$ & $1.47 \mathrm{E}-02$ & $1.74 \mathrm{E}-03$ & $3.65 \mathrm{E}-07$ & $3.48 \mathrm{E}-10$ \\
\hline 500 & 1 & 2.14 & $1.60 \mathrm{E}-03$ & $1.67 \mathrm{E}-02$ & $2.33 \mathrm{E}-03$ & $4.90 \mathrm{E}-07$ & $4.66 \mathrm{E}-10$ \\
\hline 510 & 1 & 2.14 & $1.60 \mathrm{E}-03$ & $1.69 \mathrm{E}-02$ & $2.39 \mathrm{E}-03$ & $5.03 \mathrm{E}-07$ & $4.79 \mathrm{E}-10$ \\
\hline 520 & 1 & 2.14 & $1.60 \mathrm{E}-03$ & $1.71 \mathrm{E}-02$ & $2.46 \mathrm{E}-03$ & $5.16 \mathrm{E}-07$ & $4.91 \mathrm{E}-10$ \\
\hline 530 & 1 & 2.14 & $1.60 \mathrm{E}-03$ & $1.73 \mathrm{E}-02$ & $2.52 \mathrm{E}-03$ & $5.29 \mathrm{E}-07$ & $5.04 \mathrm{E}-10$ \\
\hline 540 & 1 & 2.14 & $1.60 \mathrm{E}-03$ & $1.75 \mathrm{E}-02$ & $2.58 \mathrm{E}-03$ & $5.43 \mathrm{E}-07$ & $5.17 \mathrm{E}-10$ \\
\hline 550 & 1 & 2.14 & $1.60 \mathrm{E}-03$ & $1.77 \mathrm{E}-02$ & $2.65 \mathrm{E}-03$ & $5.56 \mathrm{E}-07$ & $5.30 \mathrm{E}-10$ \\
\hline 560 & 1 & 2.14 & $1.60 \mathrm{E}-03$ & $1.79 \mathrm{E}-02$ & $2.71 \mathrm{E}-03$ & $5.70 \mathrm{E}-07$ & $5.43 \mathrm{E}-10$ \\
\hline 570 & 1 & 2.14 & $1.60 \mathrm{E}-03$ & $1.81 \mathrm{E}-02$ & $2.78 \mathrm{E}-03$ & $5.84 \mathrm{E}-07$ & $5.56 \mathrm{E}-10$ \\
\hline 580 & 1 & 2.14 & $1.60 \mathrm{E}-03$ & $1.83 \mathrm{E}-02$ & $2.85 \mathrm{E}-03$ & $5.98 \mathrm{E}-07$ & $5.69 \mathrm{E}-10$ \\
\hline 590 & 1 & 2.14 & $1.60 \mathrm{E}-03$ & $1.84 \mathrm{E}-02$ & $2.91 \mathrm{E}-03$ & $6.12 \mathrm{E}-07$ & $5.83 \mathrm{E}-10$ \\
\hline
\end{tabular}


SRNL-STI-2013-00394

\begin{tabular}{|c|c|c|c|c|c|c|c|}
\hline $\begin{array}{l}\text { Time } \\
\text { (year) }\end{array}$ & $\begin{array}{c}\text { Th234/U238 } \\
\text { Ratio } \\
\end{array}$ & $\begin{array}{c}\text { U234/U238 } \\
\text { Ratio }\end{array}$ & $\begin{array}{c}\mathrm{Pa} 234 / \mathrm{U} 238 \\
\text { Ratio }\end{array}$ & $\begin{array}{c}\text { Th230/U238 } \\
\text { Ratio } \\
\end{array}$ & $\begin{array}{c}\text { Ra226/U238 } \\
\text { Ratio } \\
\end{array}$ & $\begin{array}{c}\text { Tl210/U238 } \\
\text { Ratio }\end{array}$ & $\begin{array}{c}\text { Rn218/U238 } \\
\text { Ratio }\end{array}$ \\
\hline 600 & 1 & 2.14 & $1.60 \mathrm{E}-03$ & $1.86 \mathrm{E}-02$ & $2.98 \mathrm{E}-03$ & $6.26 \mathrm{E}-07$ & $5.96 \mathrm{E}-10$ \\
\hline 650 & 1 & 2.14 & $1.60 \mathrm{E}-03$ & $1.96 \mathrm{E}-02$ & 3.33E-03 & 6.99E-07 & $6.66 \mathrm{E}-10$ \\
\hline 700 & 1 & 2.14 & $1.60 \mathrm{E}-03$ & 2.06E-02 & 3.69E-03 & 7.74E-07 & 7.38E-10 \\
\hline 750 & 1 & 2.14 & $1.60 \mathrm{E}-03$ & 2.16E-02 & 4.06E-03 & 8.53E-07 & $8.12 \mathrm{E}-10$ \\
\hline 800 & 1 & 2.14 & $1.60 \mathrm{E}-03$ & 2.25E-02 & 4.45E-03 & 9.34E-07 & $8.89 \mathrm{E}-10$ \\
\hline 850 & 1 & 2.14 & $1.60 \mathrm{E}-03$ & 2.35E-02 & 4.84E-03 & 1.02E-06 & $9.69 \mathrm{E}-10$ \\
\hline 900 & 1 & 2.14 & $1.60 \mathrm{E}-03$ & 2.45E-02 & $5.26 \mathrm{E}-03$ & $1.10 \mathrm{E}-06$ & 1.05E-09 \\
\hline 1,000 & 1 & 2.14 & $1.60 \mathrm{E}-03$ & 2.64E-02 & $6.11 \mathrm{E}-03$ & $1.28 \mathrm{E}-06$ & $1.22 \mathrm{E}-09$ \\
\hline 2,000 & 1 & 2.14 & $1.60 \mathrm{E}-03$ & $4.58 \mathrm{E}-02$ & 1.69E-02 & 3.55E-06 & 3.38E-09 \\
\hline 3,000 & 1 & 2.14 & $1.60 \mathrm{E}-03$ & $6.49 \mathrm{E}-02$ & $3.07 \mathrm{E}-02$ & $6.44 \mathrm{E}-06$ & $6.14 \mathrm{E}-09$ \\
\hline 4,000 & 1 & 2.13 & $1.60 \mathrm{E}-03$ & 8.39E-02 & 4.63E-02 & 9.72E-06 & $9.26 \mathrm{E}-09$ \\
\hline 5,000 & 1 & 2.13 & $1.60 \mathrm{E}-03$ & $1.03 \mathrm{E}-01$ & $6.31 \mathrm{E}-02$ & 1.32E-05 & $1.26 \mathrm{E}-08$ \\
\hline 6,000 & 1 & 2.13 & $1.60 \mathrm{E}-03$ & $1.21 \mathrm{E}-01$ & 8.05E-02 & 1.69E-05 & $1.61 \mathrm{E}-08$ \\
\hline 7,000 & 1 & 2.12 & $1.60 \mathrm{E}-03$ & 1.39E-01 & 9.82E-02 & 2.06E-05 & $1.96 \mathrm{E}-08$ \\
\hline 8,000 & 1 & 2.12 & $1.60 \mathrm{E}-03$ & $1.58 \mathrm{E}-01$ & $1.16 \mathrm{E}-01$ & $2.44 \mathrm{E}-05$ & 2.32E-08 \\
\hline 9,000 & 1 & 2.12 & $1.60 \mathrm{E}-03$ & $1.76 \mathrm{E}-01$ & $1.34 \mathrm{E}-01$ & 2.82E-05 & $2.68 \mathrm{E}-08$ \\
\hline 10,000 & 1 & 2.11 & $1.60 \mathrm{E}-03$ & 1.93E-01 & $1.52 \mathrm{E}-01$ & 3.19E-05 & 3.04E-08 \\
\hline 20,000 & 1 & 2.08 & $1.60 \mathrm{E}-03$ & 3.61E-01 & 3.23E-01 & 6.79E-05 & $6.46 \mathrm{E}-08$ \\
\hline 30,000 & 1 & 2.05 & $1.60 \mathrm{E}-03$ & 5.11E-01 & 4.77E-01 & $1.00 \mathrm{E}-04$ & $9.54 \mathrm{E}-08$ \\
\hline 40,000 & 1 & 2.02 & $1.60 \mathrm{E}-03$ & $6.45 \mathrm{E}-01$ & 6.15E-01 & 1.29E-04 & $1.23 \mathrm{E}-07$ \\
\hline 50,000 & 1 & 2.00 & $1.60 \mathrm{E}-03$ & 7.65E-01 & 7.38E-01 & $1.55 \mathrm{E}-04$ & $1.48 \mathrm{E}-07$ \\
\hline 60,000 & 1 & 1.97 & $1.60 \mathrm{E}-03$ & 8.71E-01 & $8.48 \mathrm{E}-01$ & $1.78 \mathrm{E}-04$ & $1.70 \mathrm{E}-07$ \\
\hline 70,000 & 1 & 1.94 & $1.60 \mathrm{E}-03$ & 9.67E-01 & $9.45 \mathrm{E}-01$ & $1.99 \mathrm{E}-04$ & $1.89 \mathrm{E}-07$ \\
\hline 80,000 & 1 & 1.91 & $1.60 \mathrm{E}-03$ & $1.05 \mathrm{E}+00$ & $1.03 \mathrm{E}+00$ & 2.17E-04 & $2.06 \mathrm{E}-07$ \\
\hline 90,000 & 1 & 1.89 & $1.60 \mathrm{E}-03$ & $1.13 \mathrm{E}+00$ & $1.11 \mathrm{E}+00$ & 2.33E-04 & 2.22E-07 \\
\hline 100,000 & 1 & 1.86 & $1.60 \mathrm{E}-03$ & $1.19 \mathrm{E}+00$ & $1.18 \mathrm{E}+00$ & 2.47E-04 & 2.35E-07 \\
\hline
\end{tabular}

Notes to Table 5:

1. Model U-238 and Pu-238 in the OSWDF STOMP model (decay only) to the point of assessment.

2. Multiply ratios at appropriate times by the U-238 concentration at the point of assessment to obtain the concentration of that radionuclide at the point of assessment.

3. The ratio for $\mathrm{Pa}-234 \mathrm{~m}$ is the same as that of Th-234.

4. The ratios for Rn-222, Po-218, Pb-214, Bi-214, Po-214, Pb-210, Bi-210, and Po-210 are the same as that of Ra-226.

5. The ratio for At-218 is the same as that of T-1210.

6. Data provided at times consistent with the time steps utilized within the OSWDF STOMP modeling (Lu 2013). 
Table 6. Actinium Decay Series Daughter to Parent Ratios

\begin{tabular}{|c|c|c|c|c|c|}
\hline $\begin{array}{l}\text { Time } \\
\text { (year) }\end{array}$ & $\begin{array}{c}\text { U235m/Pu239 } \\
\text { Ratio } \\
\end{array}$ & $\begin{array}{c}\text { Th231/U235 } \\
\text { Ratio }\end{array}$ & $\begin{array}{c}\text { Pa231/U235 } \\
\text { Ratio }\end{array}$ & $\begin{array}{c}\text { Fr223/U235 } \\
\text { Ratio }\end{array}$ & $\begin{array}{c}\text { Po211/U235 } \\
\text { Ratio }\end{array}$ \\
\hline 0 & 0 & 1 & 0 & 0 & 0 \\
\hline 50 & 1 & 1 & $1.06 \mathrm{E}-03$ & $7.28 \mathrm{E}-06$ & 1.45E-06 \\
\hline 100 & 1 & 1 & $2.11 \mathrm{E}-03$ & $2.04 \mathrm{E}-05$ & 4.07E-06 \\
\hline 200 & 1 & 1 & $4.22 \mathrm{E}-03$ & 4.91E-05 & 9.81E-06 \\
\hline 300 & 1 & 1 & 6.32E-03 & 7.81E-05 & 1.56E-05 \\
\hline 400 & 1 & 1 & $8.42 \mathrm{E}-03$ & 1.07E-04 & $2.14 \mathrm{E}-05$ \\
\hline 500 & 1 & 1 & 1.05E-02 & $1.36 \mathrm{E}-04$ & 2.72E-05 \\
\hline 510 & 1 & 1 & 1.07E-02 & 1.39E-04 & 2.78E-05 \\
\hline 520 & 1 & 1 & 1.09E-02 & $1.42 \mathrm{E}-04$ & 2.83E-05 \\
\hline 530 & 1 & 1 & $1.11 \mathrm{E}-02$ & $1.45 \mathrm{E}-04$ & 2.89E-05 \\
\hline 540 & 1 & 1 & $1.13 \mathrm{E}-02$ & $1.48 \mathrm{E}-04$ & $2.95 \mathrm{E}-05$ \\
\hline 550 & 1 & 1 & 1.16E-02 & $1.50 \mathrm{E}-04$ & $3.01 \mathrm{E}-05$ \\
\hline 560 & 1 & 1 & $1.18 \mathrm{E}-02$ & $1.53 \mathrm{E}-04$ & $3.06 \mathrm{E}-05$ \\
\hline 570 & 1 & 1 & $1.20 \mathrm{E}-02$ & 1.56E-04 & $3.12 \mathrm{E}-05$ \\
\hline 580 & 1 & 1 & $1.22 \mathrm{E}-02$ & $1.59 \mathrm{E}-04$ & $3.18 \mathrm{E}-05$ \\
\hline 590 & 1 & 1 & $1.24 \mathrm{E}-02$ & 1.62E-04 & 3.24E-05 \\
\hline 600 & 1 & 1 & $1.26 \mathrm{E}-02$ & $1.65 \mathrm{E}-04$ & $3.30 \mathrm{E}-05$ \\
\hline 650 & 1 & 1 & $1.36 \mathrm{E}-02$ & 1.79E-04 & $3.58 \mathrm{E}-05$ \\
\hline 700 & 1 & 1 & $1.47 \mathrm{E}-02$ & $1.94 \mathrm{E}-04$ & $3.87 \mathrm{E}-05$ \\
\hline 750 & 1 & 1 & $1.57 \mathrm{E}-02$ & $2.08 \mathrm{E}-04$ & 4.16E-05 \\
\hline 800 & 1 & 1 & $1.68 \mathrm{E}-02$ & $2.22 \mathrm{E}-04$ & 4.45E-05 \\
\hline 850 & 1 & 1 & $1.78 \mathrm{E}-02$ & 2.37E-04 & 4.73E-05 \\
\hline 900 & 1 & 1 & $1.88 \mathrm{E}-02$ & $2.51 \mathrm{E}-04$ & 5.02E-05 \\
\hline 1,000 & 1 & 1 & 2.09E-02 & $2.80 \mathrm{E}-04$ & 5.59E-05 \\
\hline 2,000 & 1 & 1 & 4.14E-02 & $5.62 \mathrm{E}-04$ & $1.12 \mathrm{E}-04$ \\
\hline 3,000 & 1 & 1 & $6.14 \mathrm{E}-02$ & $8.39 \mathrm{E}-04$ & $1.68 \mathrm{E}-04$ \\
\hline 4,000 & 1 & 1 & $8.11 \mathrm{E}-02$ & $1.11 \mathrm{E}-03$ & 2.22E-04 \\
\hline 5,000 & 1 & 1 & $1.00 \mathrm{E}-01$ & $1.38 \mathrm{E}-03$ & $2.75 \mathrm{E}-04$ \\
\hline 6,000 & 1 & 1 & $1.19 \mathrm{E}-01$ & $1.64 \mathrm{E}-03$ & $3.27 \mathrm{E}-04$ \\
\hline 7,000 & 1 & 1 & $1.38 \mathrm{E}-01$ & $1.89 \mathrm{E}-03$ & $3.78 \mathrm{E}-04$ \\
\hline 8,000 & 1 & 1 & $1.56 \mathrm{E}-01$ & $2.14 \mathrm{E}-03$ & $4.28 \mathrm{E}-04$ \\
\hline 9,000 & 1 & 1 & $1.73 \mathrm{E}-01$ & $2.38 \mathrm{E}-03$ & 4.76E-04 \\
\hline 10,000 & 1 & 1 & $1.90 \mathrm{E}-01$ & $2.62 \mathrm{E}-03$ & $5.24 \mathrm{E}-04$ \\
\hline 20,000 & 1 & 1 & 3.45E-01 & $4.75 \mathrm{E}-03$ & 9.50E-04 \\
\hline 30,000 & 1 & 1 & 4.69E-01 & $6.47 \mathrm{E}-03$ & $1.29 \mathrm{E}-03$ \\
\hline 40,000 & 1 & 1 & $5.70 \mathrm{E}-01$ & 7.87E-03 & $1.57 \mathrm{E}-03$ \\
\hline 50,000 & 1 & 1 & 6.52E-01 & $9.00 \mathrm{E}-03$ & $1.80 \mathrm{E}-03$ \\
\hline 60,000 & 1 & 1 & 7.19E-01 & $9.91 \mathrm{E}-03$ & $1.98 \mathrm{E}-03$ \\
\hline
\end{tabular}


SRNL-STI-2013-00394

\begin{tabular}{|r|r|r|r|r|r|}
\hline 70,000 & 1 & 1 & $7.72 \mathrm{E}-01$ & $1.07 \mathrm{E}-02$ & $2.13 \mathrm{E}-03$ \\
\hline 80,000 & 1 & 1 & $8.16 \mathrm{E}-01$ & $1.13 \mathrm{E}-02$ & $2.25 \mathrm{E}-03$ \\
\hline 90,000 & 1 & 1 & $8.51 \mathrm{E}-01$ & $1.17 \mathrm{E}-02$ & $2.35 \mathrm{E}-03$ \\
\hline 100,000 & 1 & 1 & $8.79 \mathrm{E}-01$ & $1.21 \mathrm{E}-02$ & $2.43 \mathrm{E}-03$ \\
\hline
\end{tabular}

Notes to Table 6:

1. Model Pu-239 and U-235 in the OSWDF STOMP model (decay only) to the point of assessment.

2. Multiply U-235m ratios at appropriate times by the U-239 concentration at the point of assessment to obtain the concentration of U-235m at the point of assessment.

3. Multiply Th-231, Pa-231, Fr-223, and Po-211 ratios at appropriate times by the U235 concentration at the point of assessment to obtain the concentration of that radionuclide at the point of assessment.

4. The ratios for Ac-227, Th-227, Ra-223, Rn-219, Po-215, Pb-211, Bi-211, and Tl-207 are the same as that of Pa-231.

5. Data provided at times consistent with the time steps utilized within the OSWDF STOMP modeling (Lu 2013).

Table 7. Thorium Decay Series Daughter to Parent Ratios

\begin{tabular}{|c|c|c|c|}
\hline $\begin{array}{l}\text { Time } \\
\text { (year) }\end{array}$ & $\begin{array}{c}\text { Th232/U236 } \\
\text { Ratio }\end{array}$ & $\begin{array}{c}\text { Po212/U236 } \\
\text { Ratio } \\
\end{array}$ & $\begin{array}{c}\text { Tl208/U236 } \\
\text { Ratio }\end{array}$ \\
\hline 0 & 7.92E-03 & 0 & 0 \\
\hline 50 & 7.92E-03 & 5.07E-03 & 2.85E-03 \\
\hline 100 & 7.92E-03 & $5.07 \mathrm{E}-03$ & $2.85 \mathrm{E}-03$ \\
\hline 200 & 7.92E-03 & $5.07 \mathrm{E}-03$ & $2.85 \mathrm{E}-03$ \\
\hline 300 & 7.92E-03 & $5.07 \mathrm{E}-03$ & $2.85 \mathrm{E}-03$ \\
\hline 400 & 7.92E-03 & 5.07E-03 & 2.85E-03 \\
\hline 500 & 7.92E-03 & 5.07E-03 & 2.85E-03 \\
\hline 510 & 7.92E-03 & 5.07E-03 & 2.85E-03 \\
\hline 520 & 7.92E-03 & 5.07E-03 & 2.85E-03 \\
\hline 530 & 7.92E-03 & 5.07E-03 & 2.85E-03 \\
\hline 540 & 7.92E-03 & 5.07E-03 & 2.85E-03 \\
\hline 550 & 7.92E-03 & $5.07 \mathrm{E}-03$ & $2.85 \mathrm{E}-03$ \\
\hline 560 & 7.92E-03 & 5.07E-03 & $2.85 \mathrm{E}-03$ \\
\hline 570 & 7.92E-03 & 5.07E-03 & 2.85E-03 \\
\hline 580 & 7.92E-03 & 5.07E-03 & 2.85E-03 \\
\hline 590 & 7.92E-03 & 5.07E-03 & 2.85E-03 \\
\hline 600 & 7.92E-03 & 5.07E-03 & 2.85E-03 \\
\hline 650 & 7.92E-03 & 5.07E-03 & 2.85E-03 \\
\hline 700 & 7.92E-03 & 5.07E-03 & 2.85E-03 \\
\hline 750 & 7.92E-03 & 5.07E-03 & 2.85E-03 \\
\hline 800 & 7.92E-03 & 5.07E-03 & 2.85E-03 \\
\hline
\end{tabular}


SRNL-STI-2013-00394

\begin{tabular}{|c|c|c|c|}
\hline $\begin{array}{l}\text { Time } \\
\text { (year) }\end{array}$ & $\begin{array}{c}\text { Th232/U236 } \\
\text { Ratio }\end{array}$ & $\begin{array}{c}\text { Po212/U236 } \\
\text { Ratio }\end{array}$ & $\begin{array}{c}\text { TI208/U236 } \\
\text { Ratio }\end{array}$ \\
\hline 850 & 7.92E-03 & 5.07E-03 & 2.85E-03 \\
\hline 900 & 7.92E-03 & 5.07E-03 & $2.85 \mathrm{E}-03$ \\
\hline 1,000 & 7.92E-03 & $5.07 \mathrm{E}-03$ & $2.85 \mathrm{E}-03$ \\
\hline 2,000 & 7.92E-03 & 5.07E-03 & $2.85 \mathrm{E}-03$ \\
\hline 3,000 & 7.92E-03 & 5.08E-03 & $2.85 \mathrm{E}-03$ \\
\hline 4,000 & 7.92E-03 & 5.08E-03 & 2.85E-03 \\
\hline 5,000 & 7.92E-03 & 5.08E-03 & $2.85 \mathrm{E}-03$ \\
\hline 6,000 & 7.92E-03 & $5.08 \mathrm{E}-03$ & $2.85 \mathrm{E}-03$ \\
\hline 7,000 & 7.92E-03 & 5.08E-03 & $2.85 \mathrm{E}-03$ \\
\hline 8,000 & 7.92E-03 & 5.08E-03 & 2.85E-03 \\
\hline 9,000 & 7.92E-03 & $5.08 \mathrm{E}-03$ & $2.85 \mathrm{E}-03$ \\
\hline 10,000 & 7.92E-03 & 5.08E-03 & 2.85E-03 \\
\hline 20,000 & 7.93E-03 & 5.08E-03 & 2.85E-03 \\
\hline 30,000 & 7.93E-03 & $5.08 \mathrm{E}-03$ & $2.85 \mathrm{E}-03$ \\
\hline 40,000 & 7.93E-03 & 5.08E-03 & 2.85E-03 \\
\hline 50,000 & 7.94E-03 & 5.08E-03 & $2.85 \mathrm{E}-03$ \\
\hline 60,000 & 7.94E-03 & 5.09E-03 & $2.85 \mathrm{E}-03$ \\
\hline 70,000 & 7.94E-03 & 5.09E-03 & $2.85 \mathrm{E}-03$ \\
\hline 80,000 & 7.94E-03 & 5.09E-03 & $2.86 \mathrm{E}-03$ \\
\hline 90,000 & 7.95E-03 & 5.09E-03 & $2.86 \mathrm{E}-03$ \\
\hline 100,000 & 7.95E-03 & 5.09E-03 & $2.86 \mathrm{E}-03$ \\
\hline
\end{tabular}

Notes to Table 7:

1. Model U-236 in the OSWDF STOMP model (decay only) to the point of assessment.

2. Multiply ratios at appropriate times by the U-236 concentration at the point of assessment to obtain the concentration of that radionuclide at the point of assessment.

3. The ratios for Ra-228, Ac-228, Th-228, Ra-224, Rn-220, Po-216, Pb-212, and Bi-212 are the same as that of Th-232.

4. Data provided at times consistent with the time steps utilized within the OSWDF STOMP modeling (Lu 2013).

Table 8. Radionuclides with Little Activity Importance over the 100,000 Year Period Modeled

\begin{tabular}{|l|l|l|l|l|}
\hline Ac225 & Bi214 & Po210 & Pu240 & Rn222 \\
\hline Ac227 & Fr221 & Po211 & Ra223 & Th227 \\
\hline Ac228 & Fr223 & Po212 & Ra224 & Th228 \\
\hline At217 & Pa234 & Po213 & Ra225 & Th232 \\
\hline At218 & Pb209 & Po214 & Ra228 & Tl207 \\
\hline Bi210 & Pb210 & Po215 & Rn218 & Tl208 \\
\hline Bi211 & Pb211 & Po216 & Rn219 & Tl209 \\
\hline Bi212 & Pb212 & Po218 & Rn220 & Tl210 \\
\hline Bi213 & Pb214 & & & \\
\hline
\end{tabular}




\subsection{REFERENCES}

Abitz 2013. Correction of slight errors in Ci inventory sheets, e-mail from Rich Abitz dated 06/12/2013.

Bateman, H. 1910. The solution of a system of differential equations occurring in the theory of radio-active transformations, Proc. Cambridge Phil. Soc., 15, p. 423.

FBP 2013. Remedial Investigation and Feasibility Study Report for the Site-Wide Waste Disposition Evaluation Project at the Portsmouth Gaseous Diffusion Plant, Piketon, Ohio, FBP-ER-RIFS-WD-RPT-0030, Revision 3, Fluor-B\&W Portsmouth LLC. February 2013

GTG 2010, GoldSim User’s Guide, Version 10.5, Service Pack 3, GoldSim Technology Group LLC, Issaquah, WA. December 2010.

ICRP 2008. Nuclear Decay Data for Dosimetric Calculations, ICRP Publication 107, Volume 38, No. 3, International Commission on Radiological Protection. 2008.

Lu 2013. Re: STOMP Model Time Steps, e-mail from Changsheng Lu dated 06/05/2013.

\subsection{ATTACHMENT - MODEL OUTPUTS}

The following model outputs are provided as an attachment to this report in DVD format due to the length of the outputs:

- The decay and daughter ingrowth output data from the GoldSim model by radionuclide over time (0 to 100,000 years) is provided in the following Excel file: “All_Rads_Inventory_R5”.

- Development of the daughter ratios by radionuclide in each decay series over time (0 to 100,000 years) is provided in the following Excel file:

“All_Rads_Inventory_R5_Daughter_Ratios_6-17-13”.

Note: Input data to the GoldSim model is provided in Tables 1 and 2. 